Review

\title{
Reactive Oxygen Species (ROS) and Antioxidants as Immunomodulators in Exercise: Implications for Heme Oxygenase and Bilirubin
}

\author{
David Travis Thomas $^{1}{ }^{(\mathbb{D}}$, Nicholas R. DelCimmuto $^{2}$, Kyle D. Flack ${ }^{3} \mathbb{D}$, David E. Stec ${ }^{4}(\mathbb{D}$ \\ and Terry D. Hinds, Jr. 5,6,7,*D
}

1 Department of Athletic Training and Clinical Nutrition, College of Health Sciences, University of Kentucky, Lexington, KY 40506, USA; dth225@uky.edu

2 Department of Neurosciences, University of Toledo College of Medicine, Toledo, OH 43614, USA; Nicholas.Delcimmuto@rockets.utoledo.edu

3 Department of Dietetics and Human Nutrition, University of Kentucky, Lexington, KY 40506, USA; kyle.flack@uky.edu

4 Center for Excellence in Cardiovascular-Renal Research, Department of Physiology \& Biophysics, University of Mississippi Medical Center, 2500 North State St, Jackson, MS 392161, USA; dstec@umc.edu

5 Department of Pharmacology and Nutritional Sciences, University of Kentucky, Lexington, KY 40508, USA

6 Barnstable Brown Diabetes Center, University of Kentucky, Lexington, KY 40508, USA

7 Markey Cancer Center, University of Kentucky, Lexington, KY 40508, USA

* Correspondence: Terry.Hinds@uky.edu

check for updates

Citation: Thomas, D.T.; DelCimmuto, N.R.; Flack, K.D.; Stec, D.E.; Hinds, T.D., Jr. Reactive Oxygen Species (ROS) and Antioxidants as Immunomodulators in Exercise: Implications for Heme Oxygenase and Bilirubin. Antioxidants 2022, 11 179. https://doi.org/10.3390/ antiox11020179

Academic Editors: Elias Lianos and Maria G. Detsika

Received: 9 December 2021

Accepted: 14 January 2022

Published: 18 January 2022

Publisher's Note: MDPI stays neutral with regard to jurisdictional claims in published maps and institutional affiliations.

Copyright: () 2022 by the authors Licensee MDPI, Basel, Switzerland. This article is an open access article distributed under the terms and conditions of the Creative Commons Attribution (CC BY) license (https:// creativecommons.org/licenses/by/ $4.0 /)$.

\begin{abstract}
Exercise is commonly prescribed as a lifestyle treatment for chronic metabolic diseases as it functions as an insulin sensitizer, cardio-protectant, and essential lifestyle tool for effective weight maintenance. Exercise boosts the production of reactive oxygen species (ROS) and subsequent transient oxidative damage, which also upregulates counterbalancing endogenous antioxidants to protect from ROS-induced damage and inflammation. Exercise elevates heme oxygenase-1 (HO-1) and biliverdin reductase A (BVRA) expression as built-in protective mechanisms, which produce the most potent antioxidant, bilirubin. Together, these mitigate inflammation and adiposity. Moderately raising plasma bilirubin protects in two ways: (1) via its antioxidant capacity to reduce ROS and inflammation, and (2) its newly defined function as a hormone that activates the nuclear receptor transcription factor PPAR $\alpha$. It is now understood that increasing plasma bilirubin can also drive metabolic adaptions, which improve deleterious outcomes of weight gain and obesity, such as inflammation, type II diabetes, and cardiovascular diseases. The main objective of this review is to describe the function of bilirubin as an antioxidant and metabolic hormone and how the HO-1BVRA-bilirubin-PPAR $\alpha$ axis influences inflammation, metabolic function and interacts with exercise to improve outcomes of weight management.
\end{abstract}

Keywords: HO-1; biliverdin reductase; BVRA; PPAR $\alpha$; bilirubin; inflammation; metabolic disease; nutraceuticals; vitamin D; vitamin E; nitrate

\section{Introduction}

Obesity and ectopic lipid accumulation are key contributing hallmarks of metabolic dysfunction, which is the cornerstone of pathogenesis for most comorbidities [1-3]. People with a BMI greater than 30 (>30) have an increased risk for obesity-associated comorbidities that include cardiovascular disease, hypertension, insulin-resistant diabetes, dyslipidemia, and certain cancers [4-7]. Alterations in lipid metabolism also contribute to ectopic lipid accumulation, exacerbating metabolic disorders, especially when combined with limited physical activity. Understanding and combating metabolic dysfunction is essential for improving clinical outcomes and quality of life. 
Obesity treatment has been challenging, and exercise continues to be the foundation for obesity prevention and treatment. Despite the continued interest in exercise training in obesity, there are still challenges, including patients falling short on meeting exercise recommendations over time and limited effectiveness of exercise as a sole driver for stimulating weight loss [8-10].

A common theme found in the literature on the healthy athletic population is how different nutrients, hormones, dietary supplements, and other forms of ergogenic aids [referred to herein as "exercise enhancers" (EEs)] can improve exercise training outcomes to enhance athletic performance. There is also emerging evidence that EEs may augment the metabolic benefits of exercise and, in some cases, modulate inflammation. This review provides a brief overview of exercise in preventing metabolic dysfunction along with the potential role of select antioxidants (i.e., bilirubin and others), vitamin D, and nitrates on improving metabolic outcomes associated with exercise. The primary focus will then shift to describing bilirubin's emerging significance as a potential EE due to its role as a strong antioxidant and metabolic hormone.

This review describes how exercise interacts with bilirubin to further sensitize these newly defined antioxidant and protective metabolic functions as a hormone. The role of exercise and its influence on bilirubin catabolism will be discussed along with proposed theories on how bilirubin may influence physiological adaptations associated with exercise training and how this might impact inflammatory responses. A primary mechanism discussed postulates that as exercise increases reactive oxygen species (ROS) production, increased heme oxygenase (HO-1) activity raises plasma bilirubin levels, which can also directly bind and activate $\operatorname{PPAR} \alpha$ (peroxisome proliferator-activated receptor $\alpha$ ) in metabolic tissues (e.g., adipose, liver, and muscle), which might explain some of the therapeutic benefits observed with exercise (Figure 1). Other important mediators such as HO-1 and PPARs and their impact on exercise and inflammation will be discussed.

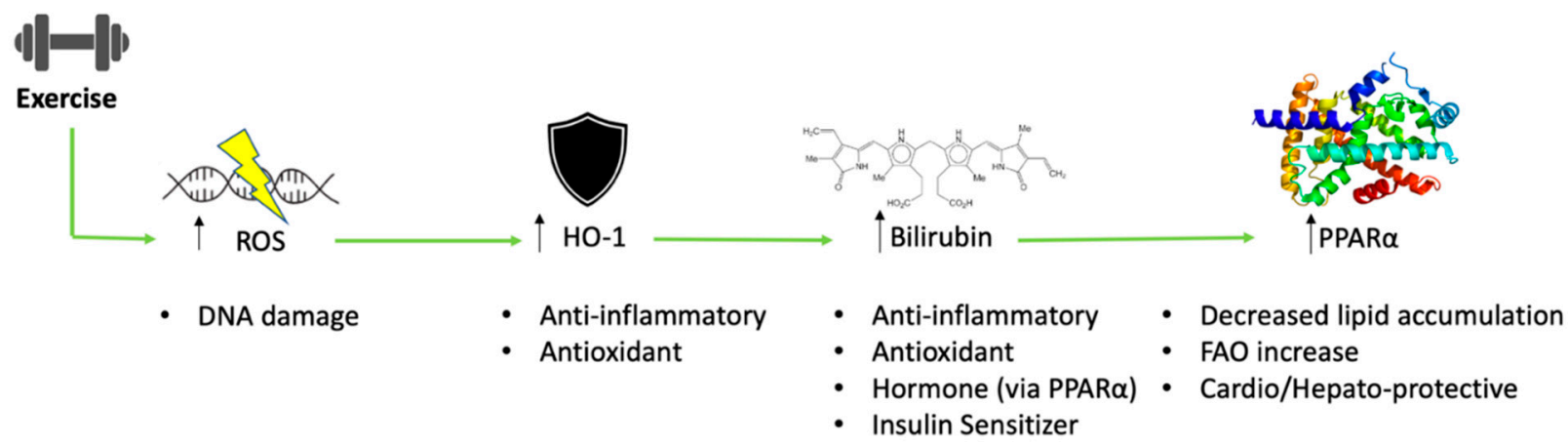

Figure 1. Overview of heme oxygenase and bilirubin interaction with exercise. Exercise increases reactive oxygen species (ROS) and potentiates oxidative DNA damage. The body compensates with oxidative stress by upregulating heme oxygenase- 1 (HO-1), which generates the antioxidant bilirubin to help prevent excessive oxidative damage. Bilirubin also directly binds to the PPAR $\alpha$ nuclear receptor to induce genes that suppress lipid accumulation and has cardiogenic and hepato-protective effects.

\section{The Effect of Exercise on Weight Management and Inflammation}

Exercise is regularly prescribed as a first-line treatment in preventing type 2 diabetes, coronary artery disease (CAD), and non-alcoholic fatty liver disease (NAFLD) [11-13]. It has strong therapeutic effects that usually meet or exceed expected improvements in metabolic function from pharmaceutical treatment [14]. Exercise training triggers significant metabolic adaptations that improve cardiorespiratory fitness, promoting greater capillary density and increase in HDL synthesis to protect from CAD [14,15]. Exercise also enhances glucose uptake through elevating translocation of GLUT4 in skeletal muscle and by increasing IRS-1 phosphorylation, an insulin receptor substrate that improves insulin sensitivity [16,17]. Therefore, exercise can be a reliable first-line and preventative therapeutic for type II 
diabetes by decreasing blood glucose [18] and CAD by reducing atherosclerotic plaque buildup and subsequent risk of stroke and myocardial infarction [19].

Although exercise training can improve blood glucose control, insulin sensitivity, and other aspects of metabolic syndrome without weight loss, these benefits are substantially greater when significant weight loss occurs [20-23]. Indeed, the American College of Sports Medicine issued separate recommendations to maintain health [24] or support weight loss through exercise [25]. Exercise is also one of the primary recommendations of the Diabetes Prevention Program (DPP) and a pivotal component to the classic Look AHEAD trial primarily due to the role that exercise is thought to play in weight loss and weight management $[26,27]$. Unfortunately, weight loss from exercise is often suboptimal due to compensatory mechanisms that resist the maintenance of an energy deficit [8-10]. For instance, an individual may exercise to expend $3000 \mathrm{kcal}$ per week for ten weeks through exercise to expend a total of 30,000 kcal. However, this individual rarely loses 30,000 kcal of body mass. By comparing changes in bodily energy stores with the amount of total energy expended through exercise, we have demonstrated this compensatory response to equate to roughly $1000 \mathrm{kcal}$ per week during a 12-week exercise intervention, and that energy expenditures of greater than $2700 \mathrm{kcal}$ per week are needed to achieve significant weight loss after 12 weeks. [28,29]. Others have reported that greater amounts of exercise can evoke a proportionally greater compensatory response [30], potentially explaining why exercise interventions with large differences in daily and weekly exercise energy expenditures can promote similar weight loss [30-33]. Because of this, many have turned to various EE's to improve both weight loss and metabolic health outcomes with exercise. We will discuss some specific studies on EE's below and how they might impact exercise-induced ROS and inflammation.

\section{Exercise-Induced Formation of Reactive Oxygen Species and Select Antioxidant Defense Mechanisms}

ROS generation from exercise has a significant role in triggering and sustaining the healthy cellular, tissue, and organ level adaptations that help improve and maintain cardiometabolic health. Acute ROS generation from exercise occurs via electron transport oxygen catabolism in the skeletal muscle. This is triggered by a substantial increase in mitochondrial oxygen uptake into the skeletal muscle cell, increasing ROS production [34]. Exercise-induced ROS production can also produce muscle injury, which sends inflammatory signals that attract polymorphonuclear neutrophils and macrophages and produce additional ROS in its defense mechanism of oxidative burst [35]. If there is a chronic imbalance of more ROS production than antioxidant activity, chronic oxidative stress may lead to apoptotic pathways in tissues [36]. A skeletal muscle oxidative stress imbalance is commonly seen in untrained individuals who begin a strenuous training program or "weekend-warriors" who perform a single bout of infrequent strenuous exercise (Figure 2). Although exercise is known to increase the abundance of ROS, progressive exercise training allows time for the upregulation of defense mechanisms that help protect the body from oxidative damage. This is known as redox balance (Figure 3), where free radicals are balanced by the adaptive antioxidants produced [37]. Exercise may stimulate the generation of antioxidants by triggering significant cell adaptations and upregulating antioxidantproducing enzymes [38]. Those who are exercise-trained and perform a single bout of exercise can leverage the benefits of endogenous antioxidant upregulation, along with mitochondrial expansion, cryoprotection, and insulin sensitivity [35]. The importance of ROS is highlighted in experimental models treated with allopurinol. This compound inhibits ROS production and protects muscle tissue from oxidative stress. However, because exercise-induced ROS was not produced, the important adaptive signaling pathways for oxidative protection were blunted. Thus, the formation of ROS in exercise can help activate these intrinsic protective pathways. Notwithstanding, allopurinol is a competitive inhibitor for xanthine oxidase that produces $\mathrm{H}_{2} \mathrm{O}_{2} \cdot \mathrm{H}_{2} \mathrm{O}_{2}$ is a kind of ROS; thus, xanthine oxidase is an intrinsic prooxidant. This adaptive signaling response is an important body regulation, 
and if extrinsic, pharmaceutical dose antioxidants are administered, the body's natural adaptive ability to produce in trinsic antioxidants may be thwarted [38].
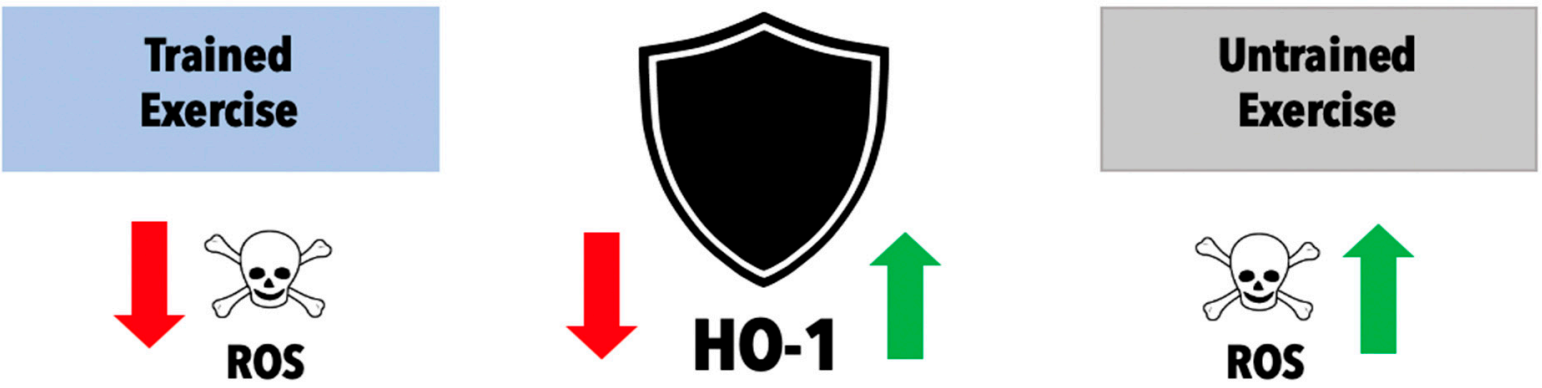

Figure 2. Relationship of HO-1 and ROS in habitually trained versus untrained subjects. Individuals who have performed a single bout of exercise (non-trained) versus individuals with exercise training experience (trained).

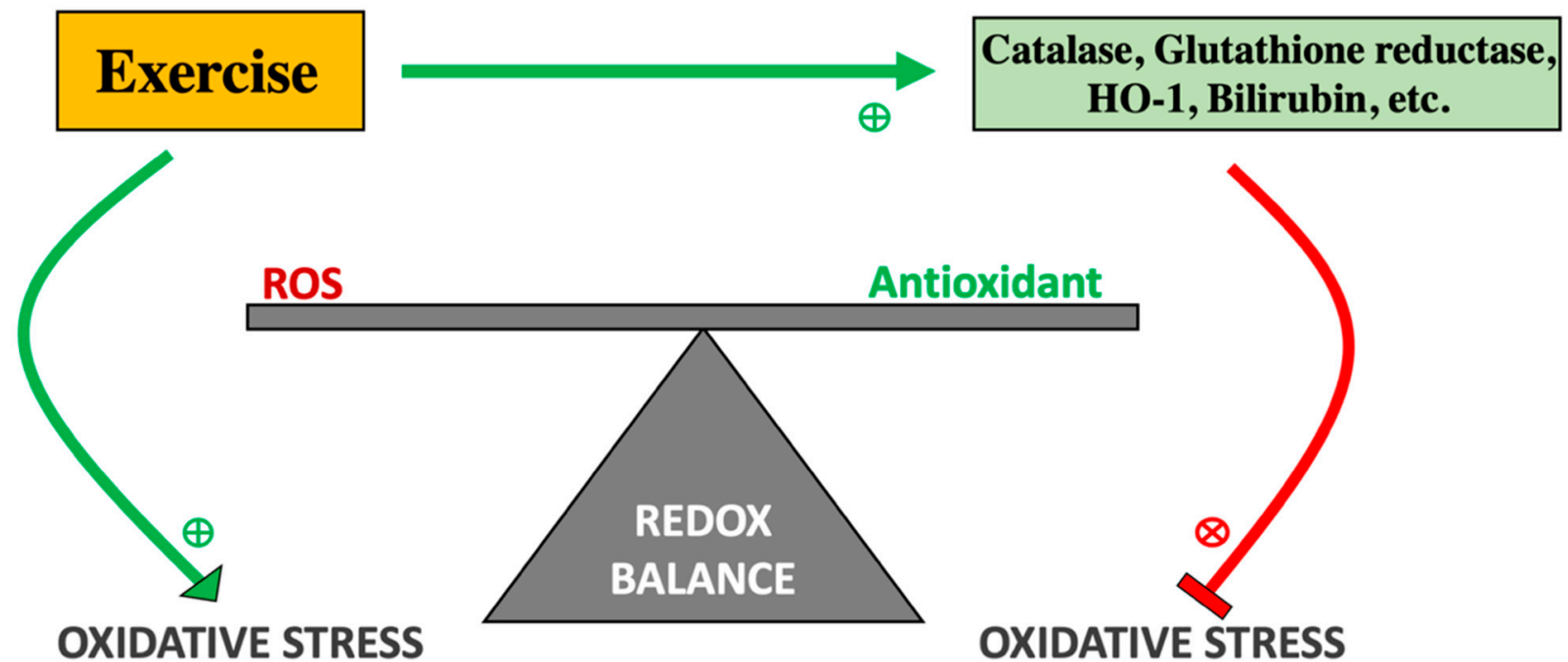

Figure 3. Redox Balance of ROS and Antioxidants. Exercise potentiates the release of reactive oxygen species due to increased oxidative exposure. However, exercise training also induces an adaptive response with the upregulation of antioxidant defense mechanisms that will help restore redox balance. The downregulation of endogenous antioxidant systems or the increased production of reactive oxygen species can precipitate an imbalance in redox balance and potentiate chronic oxidative damage.

Ultimately, exercise-related ROS adaptations improve oxygen transport and delivery that translate into better aerobic fitness that help explain many of the health benefits of exercise. Furthermore, upregulation of endogenous antioxidant systems can work in concert with exogenous dietary antioxidants to mitigate ROS-related tissue damage and support normal metabolic function and healthy aging. Conversely, the accumulation of ROS and inadequate ROS defense responses has been implicated as a key mechanism leading to significant atrophy in muscle tissue. Muscle atrophy due to chronic excessive ROS exposure progresses slowly as part of the normal aging process but is more pronounced and accelerated in severe underlying pathological processes such as in cancer wasting (cancer cachexia) [39], neurodegenerative diseases (Parkinson's, Alzheimer's), and immobilization (musculoskeletal injury) [40]. 


\section{HO-1, BVRA, and Bilirubin as Inflammatory Mediators}

\subsection{Exercise-Induced HO-1 as a Mediator of Immune System Responses}

$\mathrm{HO}-1$ produces a known potent antioxidant and enzyme responsible for the cleavage of heme, yielding biliverdin, iron $\left(\mathrm{Fe}^{2+}\right)$, and carbon monoxide (CO) $[41,42]$. The HO1 pathway also regulates some of the metabolic and inflammatory aspects of insulin resistance. While there is a connection between inflammation and the development of insulin resistance, it is unclear which development precedes and which is causative [43]. HO-1's role in inflammation and insulin resistance appears equivocal in the literature.

The presence of HO-1 mimics the same efficacious properties as bilirubin [44]. Bilirubin downregulates the M1 macrophages associated with the release of pro-inflammatory cytokines [45-47]. Future work to understand how HO-1 may affect M1 cells may shed light on potential underlying mechanisms to explain how bilirubin downregulates M1 cells. HO-1 also protects the liver from ischemia-reperfusion injury by modulating the macrophage phenotype into the anti-inflammatory M2 state in mouse livers [48,49]. This serves as evidence for an $\mathrm{HO}-1$ role as a hepatic cryoprotective agent. In this same study, low HO-1 mRNA levels in human liver transplants correlated with increased expression of M1 pro-inflammatory markers [48,49]. Liver-specific biliverdin reductase A (BVRA) knockout animals with reduced hepatic bilirubin had worsened fatty liver on a high-fat diet compared to littermate controls [50], which was confirmed in global BVRA knockout animals [51]. Bilirubin reduces lipid content and inflammatory markers in mouse models of obesity-induced NAFLD $[46,47]$.

Work by Gobert et al. found HO-1 to prevent an inflammatory response and has implicated HO-1 as a virulence factor in $H$. Pylori and other bacteria in order to evade the immune system [52]. Other work has described using a heme-inducing compound to effectively reduce obesity, insulin sensitivity and increase serum adiponectin levels. Inhibition of the HO-1 system decreased adiponectin and increased pro-inflammatory cytokines, TNF $\alpha$, IL-6, and IL-1 [53-55]. Adiponectin, a known anti-inflammatory hormone, is thought to be working indirectly through HO-1-activation [56]. The complete mechanism of this anti-inflammatory activity is not fully understood, but some theories with convincing evidence reveal new insight on $\mathrm{HO}-1$ and the importance of its catabolic products.

The HO-1 pathway can decrease inflammation by producing biliverdin/bilirubin, which has protective anti-inflammatory effects, especially in vascular endothelial tissue [57]. Another anti-inflammatory action of $\mathrm{HO}-1$ is through carbon monoxide production, which is a known cryoprotectant and anti-apoptotic factor in endothelial cells that have the potential to crosstalk with nitric oxide, a known vasodilator. Although this work serves as further evidence that HO-1 has important underlying anti-inflammatory and insulinsensitizing mechanisms that may augment bilirubin's therapeutic value, it is essential to note that the supporting evidence is not unequivocal. In contrast to these aforementioned findings, conflicting data suggest that $\mathrm{HO}-1$ is implicated in driving inflammation and may even support insulin resistance in humans. Jais et al. demonstrated that HO-1 levels predict a strong positive prediction of metabolic disease in human subjects [58], while Ghio et al. reported HO-1 elevation due to cytokine stimulation in inflammatory disease [59]. Whether $\mathrm{HO}-1$ is present in response to the inflammation or if it is the direct cause of inflammation is not completely clear.

Although HO-1's direct role on insulin resistance and inflammation has not been fully elucidated, the influence of exercise on the HO-1 pathway may shed light on these equivocal data. Niess et al. showed that HO-1 expression in leukocytes increased significantly after sustained endurance exercise in marathon runners. The authors interpreted this to be due to the excessive amount of free radical production, although the mechanism that causes this upregulation of HO-1 in exercise is not completely clear [60]. However, it can be postulated that since exercise promotes ROS generation, it would induce nuclear factor (erythroid-derived 2)-like-2 (Nrf2) expression, which is a key transcription factor in inducing HO-1 [61-63]. A potential explanation for the upregulation of HO-1 may be that acute exercise can also propagate a transient pro-inflammatory state to increase levels 
of HO-1 via increased cytokine activity. Others have suggested that ROS, themselves, can induce and upregulate HO-1. Kurata et al. found that the $\mathrm{HO}$ gene was induced by 12-O-tetradecanoylphorbol 13-acetate response element (TRE) in the presence of hydrogen peroxide, a ROS [64]. These oxidative free radical levels vary based on habitually trained versus untrained subjects. The trained individuals had a much more robust adaptive antioxidant defense system and thus a lower level of ROS production [65]. HO-1 levels at rest are significantly reduced in trained subjects compared to untrained subjects [60]. This suggests an adaptive regulatory feedback mechanism to which, at rest, basal ROS are downregulated in trained individuals and hence, a lower HO-1 level. The prevailing hypothesis surrounding this observation is that $\mathrm{HO}-1$ is upregulated to offer protection from the free radicals that are produced with exercise (Figure 3) [59].

\subsection{The Emerging Role of Biliverdin Reductase in Immune Response}

BVRA plays a vital role in macrophage polarization and as a target for regulating responses to bacterial lipopolysaccharides and complement activation products. BVRA is expressed in macrophages where it is tyrosine phosphorylated. Phosphorylated BVRA then binds to phosphatidylinositol 3-kinase (PI3K) at the p85 $\alpha$ subunit to activate downstream signaling to Akt $[66,67]$. Macrophage classification occurs according to activation state and function. M-1 macrophages are classically activated macrophages that express cytokines such as TNF $\alpha$ and interleukin-17A. M-2 macrophages are alternatively activated macrophages that express anti-inflammatory cytokines such as interleukin-10 (IL-10) and transforming growth factor-beta (TGF $\beta$ ). Overexpression of BVRA in macrophages elevates expression of M-2 macrophage markers, while knockdown of BVRA increases M-1 macrophage markers [68]. Renal ischemia-reperfusion injury increases the levels of BVRA positive macrophages increasing the levels of IL-10, helping in the reparative process [68]. The recruitment of macrophages is an influential process in the inflammatory response. Release of chemokines that act on specific receptors such as the complement activation fragment 5a receptor one (C5aR1) recruits macrophages to sites of tissue injury. Loss of macrophage BVRA results in greater levels of C5aR1 increasing inflammation [69]. These studies demonstrate the critical role of BVRA in both macrophage chemotaxis and polarization. Augmentation of macrophage BVRA levels may be an effective treatment to bolster anti-inflammatory pathways in a number of inflammatory diseases. How they might affect metabolic adaptations to exercise is yet to be determined.

\subsection{The Effect of Exercise on Bilirubin and Its Actions}

Given that HO-1 expression is directly influenced by exercise training (Figure 4), it is logical to assume that exercise increases plasma bilirubin levels. Hinds et al. recently conducted a study where rats genetically selected for high capacity running (HCR) and low capacity running (LCR) were used to identify the metabolic pathways in the liver altering plasma bilirubin levels through exercise [70]. The investigators observed that HCR rats had significantly greater plasma bilirubin and hepatic BVRA expression while having a reduced expression of the glucuronyl hepatic enzyme UGT1A1. Significant increases in PPAR $\alpha$-target genes were also observed in HCR rats compared to the LCR. For the first time, these results suggest hepatic mechanisms involved in bilirubin synthesis and metabolism that may explain the positive effects of exercise on plasma bilirubin and metabolic health.

There are a limited number of articles published on this topic in humans [71,72]. In a controlled study that examined different levels of training intensity, researchers found that the high-intensity training group (defined as 12 kilocalories per kilogram per week (KKW) energy expenditure) presented a significant increase in total serum bilirubin in comparison to the sedentary control group. Those who trained at moderate intensity levels (defined as 4 and $8 \mathrm{KKW}$ ) experienced no significant differences in serum bilirubin levels [71]. Priest et al. observed an increase in bilirubin in male runners after a 13-mile run along with an increase in alkaline phosphatase. Bile acids and bilirubin have been shown to be elevated 
in these runners [73]. In both studies, bilirubin levels seem to be elevated in response to high-volume, exhaustive forms of exercise with high energy expenditure.

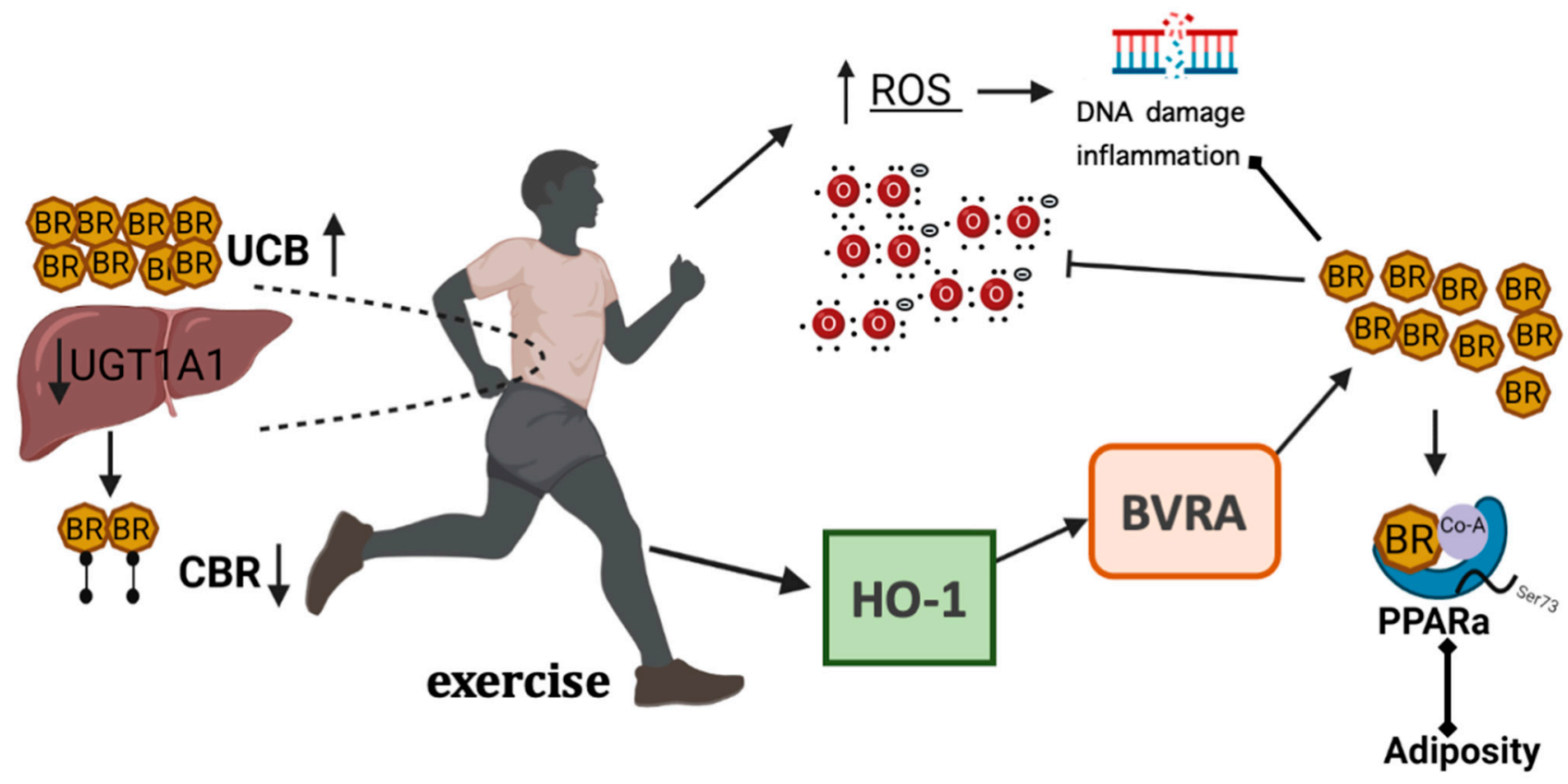

Figure 4. The heme oxygenase pathway signaling during exercise. Exercising (aerobic) raises plasma bilirubin levels by (1) suppression of the glucuronyl transferase enzyme UGT1A1 that conjugates bilirubin for removal from blood, and (2) activation of the heme oxygenase pathway (HO1-BVRA-PPAR $\alpha$ ). The increased bilirubin combats reactive oxygen species (ROS) and ROS-induced inflammation and DNA damage. The bilirubin also activates the nuclear receptor transcription factor, $\operatorname{PPAR} \alpha$, to reduce adiposity. Created with BioRender.com (accessed on 9 December 2021).

A subgroup analysis from Swift et al. revealed another interesting trend that showed those who were insulin resistant in the high-intensity exercise group had a significant increase in bilirubin compared to the insulin-sensitive group [71]. A more recent study confirmed these observations by examining why moderate-to-vigorous physical activity (MVPA) resulted in a significant increase in serum bilirubin in insulin-resistant subjects but not in insulin-sensitive subjects. The authors hypothesized that the observed increase in bilirubin in the insulin-resistant subjects could be due to a lower basal level of bilirubin, resulting in a more remarkable absolute change in bilirubin in response to MVPA [74]. The underlying rationale for this pattern of bilirubin change in response to different exercise volumes should be further explored to improve our understanding of the connection between insulin resistance and changing bilirubin levels.

Several studies in athletes have also reported a strong correlation between elevated bilirubin and the degree of exercise intensity and an associated increase in erythrocyte hemolysis [71,75-77]. Witek et al. reported normal bilirubin reference ranges for 339 male and female Polish athletes [72]. While approximately $45 \%$ of the samples had bilirubin levels in the range of $7-14 \mu \mathrm{M}, 12 \%$ of the athletes had $21-28 \mu \mathrm{M}$. Nineteen percent of the total bilirubin values exceeded the established normal limit of $21 \mu \mathrm{M}$. These elevated concentrations appeared to be related to changes caused by regular exercise and were not directly related to increased hemolysis. The authors suggested that other exercise-induced mechanisms seem to affect bilirubin concentrations, such as altered liver function and upregulation of bilirubin production (to serve as an antioxidant) in response to increased oxidative stress (ROS). A study of young Polish athletes (aged 18-40 years) reported that bilirubin levels increased in response to both a ketogenic diet and short-term, high-intensity exercise (CrossFit) [78]. Study subjects increased their bilirubin concentrations in both diet groups in response to exercise (Customary diet: $10 \pm 5$ to $19 \pm 8$; Ketogenic diet: 
$14 \pm 0$ to $20 \pm 8 \mu \mathrm{M} ; p<0.05)$. These studies bring to question if bilirubin levels are being controlled by exercise to correct metabolic imbalances, mitigate oxidative stress, and reduce inflammation.

\subsection{The Hormonal Function of Bilirubin in Exercise and the Impact of PPAR Signaling}

The PPARs are a subfamily of ligand-activated nuclear receptor transcription factors with three distinct isoforms: $\alpha, \beta / \delta, \gamma$ [79]. These isoforms are found in different tissues, each with a predominant isoform. PPAR $\alpha$ is expressed in hepatocytes, enterocytes, and vascular endothelium and works to improve mitochondrial efficacy in FA oxidation in these tissue types. PPAR $\beta / \delta$ are expressed more ubiquitously in the body but predominate in skeletal muscle and macrophages and are important in fatty acid oxidation and macrophage immunosuppression through the reduction in NF- $\mathrm{kB}$ inflammatory cytokines [80,81]. PPAR $\gamma$ is found mainly in white and brown fat adipocytes and enhances genes involved in the metabolism of glucose and adipocyte differentiation [82-86]. PPAR's are activated in the presence of their specific corresponding natural or synthetic pharmacological ligands. All PPAR isoforms will activate in the presence of unsaturated fatty acid (PPAR pan agonist), which acts as a ligand to the PPAR isoforms [87]. It should be noted that all of the PPAR isoforms are considered to drive anti-inflammatory pathways. A hepatocyte-specific and adipocyte-specific knockout of PPAR $\alpha$ in mice fed a high-fat diet showed greater fat content in each of the KOs, which both also exhibited significantly higher inflammation compared to control littermates [88,89]. Similarly, studies showing that overexpression of inflammatory meditator glucocorticoid receptor beta (GR $\beta)$ in the liver of $\mathrm{C} 57 / \mathrm{bl} 6$ mice induced hepatic lipid accumulation in 5 days on a normal chow diet by suppression of hepatic PPAR $\alpha$ [90].

We have shown that bilirubin (unconjugated form) binds directly to the PPAR $\alpha$ nuclear receptor to induce transcription of genes (Figure 5) [91-94], which control adiposity and glucose sensitivity. Interestingly, competitive binding studies and transcriptional activity assays demonstrated that bilirubin's binding to the PPARs is specific to only PPAR $\alpha$, and it has no actions or binding to PPAR $\gamma$ or PPAR $\beta / \delta$ [91,92]. In looking more specifically at ligands for PPAR $\alpha$, a synthetic ligand such as fenofibrate (fibrates) is widely used in the treatment of hypertriglyceridemia in order to reduce serum triglyceride levels. Through the binding and subsequent activation of the PPAR $\alpha$ nuclear receptor, fenofibrate reduces plasma triglycerides and VLDL/LDL concentrations [95]. An increased expression of PPAR $\alpha$ offers significant induction of $\beta$-oxidation $[46,47,63,92,94]$ and myocardial ATP production, which are markers for myocardial viability [96,97]. It can also reduce the oxidative stress that occurs after a high-fat meal [95]. As mentioned above, unconjugated bilirubin has been demonstrated to act as a novel endocrine ligand that activates the transcriptional activity of PPAR $\alpha$ by direct interaction, which changes coregulator proteins bound to the nuclear receptor to control gene activity [92]. PPAR $\alpha$ activation by bilirubin in obese mice with glucose intolerance leads to a decrease in fasting blood glucose, as well increase in lean body mass and an increased presence of FGF21 (fibroblast growth factor 21) [42]. FGF21 can act as a metabolic regulator by rapid reduction in blood glucose and insulin levels in obese models [42,98] (readers are referred to another review discussing modulation of metabolism by FGF21 for more information [99]). The impact that bilirubin has on exercise via FGF21 is unknown. More studies are needed to elucidate the protective properties of bilirubin that occur via it driving the PPAR $\alpha$-FGF21 pathway that reduces adiposity and improves insulin sensitivity. 


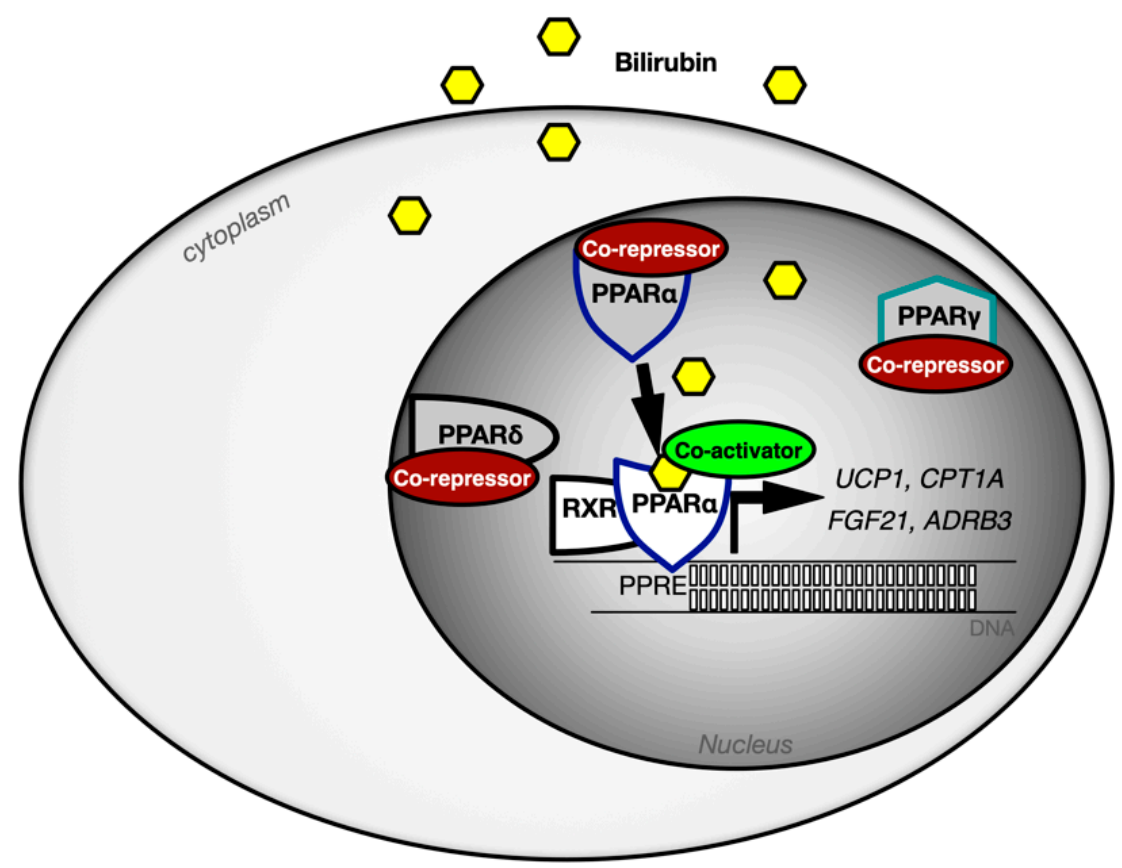

Figure 5. Selectivity of bilirubin for the PPAR isoforms and signaling mechanisms. The PPAR isoforms are bound by corepressors proteins until they are bound to the ligand, which induces a change from co-repressors to co-activators. Unconjugated bilirubin enters the cells and activates PPAR $\alpha$ and not the PPAR $\gamma$ or PPAR $\beta / \delta$ isoforms. Bilirubin binding to PPAR $\alpha$ induces a complex with RXR causing an exchange of corepressor proteins for co-activators. The bilirubin-induced PPAR $\alpha$-RXR complex controls specific genes for metabolic control of adiposity (UCP1, CPT1A, FGF21, $A D R B 3$, and others), which might be based upon specific co-activators (PGC1 $\alpha$, NCOA1, NCOA2, MED1, etc.) bound in the complex.

Exercise plays a role in the activation of the PPAR systems. Exercise increases the levels of AMP-activated kinase (AMPK), ERK1/2-MAPK, and PKC, which are kinases in the skeletal muscle involved in increasing the expression of downstream transcription factors. These kinases are found to increase the transactivation of PPAR $\alpha$ and thus an increase in FA oxidation and glucose production, which can be used as fuel during exercise [100]. PPAR $\alpha$, in particular, has strong actions on improving the efficacy of FA oxidation in the liver and adipose tissues [88,89]. PPAR $\alpha$ mRNA upregulates in bouts of exercise and in times of starvation in order to metabolize fat and use it for an effective energy source [101,102]. Acute exercise also provides increases in liver and serum FGF21, which provides systemic insulin sensitization [103]. PPAR $\alpha$ expression is necessary for optimized endurance exercise. PPAR $\alpha$ knockout models had significantly less tolerance to endurance exercise than the control. This lack of tolerance is due to a rapid depletion of hepatic glycogen [104]. We have shown that reducing PPAR $\alpha$ activity in the liver leads to lower hepatic glycogen content $[88,90]$, and activation by bilirubin increases it $[47,70]$. Similarly, hepatocyte-specific BVRA knockout animals on a high-fat diet had reduced bilirubinPPAR $\alpha$ activity and lower glycogen levels [50]. Endurance athletes were found to have a specific polymorphism that produces an increased binding capacity of PPAR $\alpha$ in skeletal muscle and more type I slow-twitch fibers [105]. This suggests that PPAR $\alpha$ may have critical roles in exercise and is necessary to perform enhanced endurance activity [106]. Similar to PPAR $\alpha, \operatorname{PPAR} \gamma$ and PPAR $\beta / \delta \mathrm{mRNA}$ is also elevated as a result of an aerobic exercise training program $[107,108]$. PPAR $\beta / \delta$ are the least studied of the isoforms. There is evidence to support PPAR $\beta / \delta$ 's ability to rectify metabolic disorders and enhance $\beta$ oxidation in muscle [109]. Many of its effects mimic the functionality of PPAR $\alpha$; however, the PPAR $\beta / \delta$ is more ubiquitously expressed than PPAR $\alpha$ [110]. 
PPAR $\gamma$ is upregulated after sustained exercise programs and showed beneficial effects in skeletal muscle [111]. This skeletal muscle had signs of mitochondrial biogenesis and thus, improved aerobic respiration. The mitochondrial biogenesis is also seen in adipose tissue and is phenotypically evident by the increased conversion of white fat into brown fat in the presence of a highly induced PPAR $\gamma$ [112]. This exercise-induced PPAR $\gamma$ can provide antidiabetic effects through upregulation of monocyte PPAR $\gamma$-control genes [111]. PPAR $\gamma$ is also in charge of controlling adipocyte differentiation $[113,114]$. In a PPAR $\gamma$ knockout model, severe lipoatrophy is observed, along with insulin resistance [115]. The PPAR $\gamma$ knockout mice have significantly decreased body mass; however, the liver showed a 1.5-fold increase in weight and increased lipid deposition in hepatic tissue. The increased lipid deposition in the liver is due to disrupted adipogenesis in white adipose tissue (WAT), causing increased plasma triglycerides that can deposit in the liver [116]. These PPAR systems have been correlated with decreased levels of atherosclerosis, insulin resistance, and inflammation in conjunction with metabolic syndrome and hypertriglyceridemia [114].

Another novel metabolic role designated to bilirubin is its natural ability to act as an insulin sensitizer [44,117]. PPAR $\gamma$ is elevated following bilirubin administration in mice with improved insulin sensitivity. This isomer of PPAR is implicated as a potent factor in adipocyte differentiation and adiponectin secretion [117]. Bilirubin administration has also improved obesity and hyperglycemia in rodent models. Bilirubin-treated obese mice increased phosphorylation of Akt (Thr309), an insulin-signaling molecule, in skeletal muscle and hepatocytes, indicating preservation of insulin sensitivity [44]. Bilirubin-treated mice also presented with greater adiponectin levels [117]. It should be noted that while bilirubin induced PPAR $\gamma$ expression in diabetic mice, it is not a ligand for this receptor as was previously demonstrated [91,92]. Because bilirubin levels rise with exercise more effectively in insulin-resistant subjects, there is therapeutic potential for bilirubin to control cholesterol metabolism and glucose tolerance in insulin-resistant patients. Therefore, exercise in pre-diabetic patients may offer metabolic benefits by raising HO-1, upregulating adiponectin and bilirubin levels, enhancing insulin signaling, activating PPAR $\alpha$ pathways, and thus, decreasing insulin resistance (Figure 6).

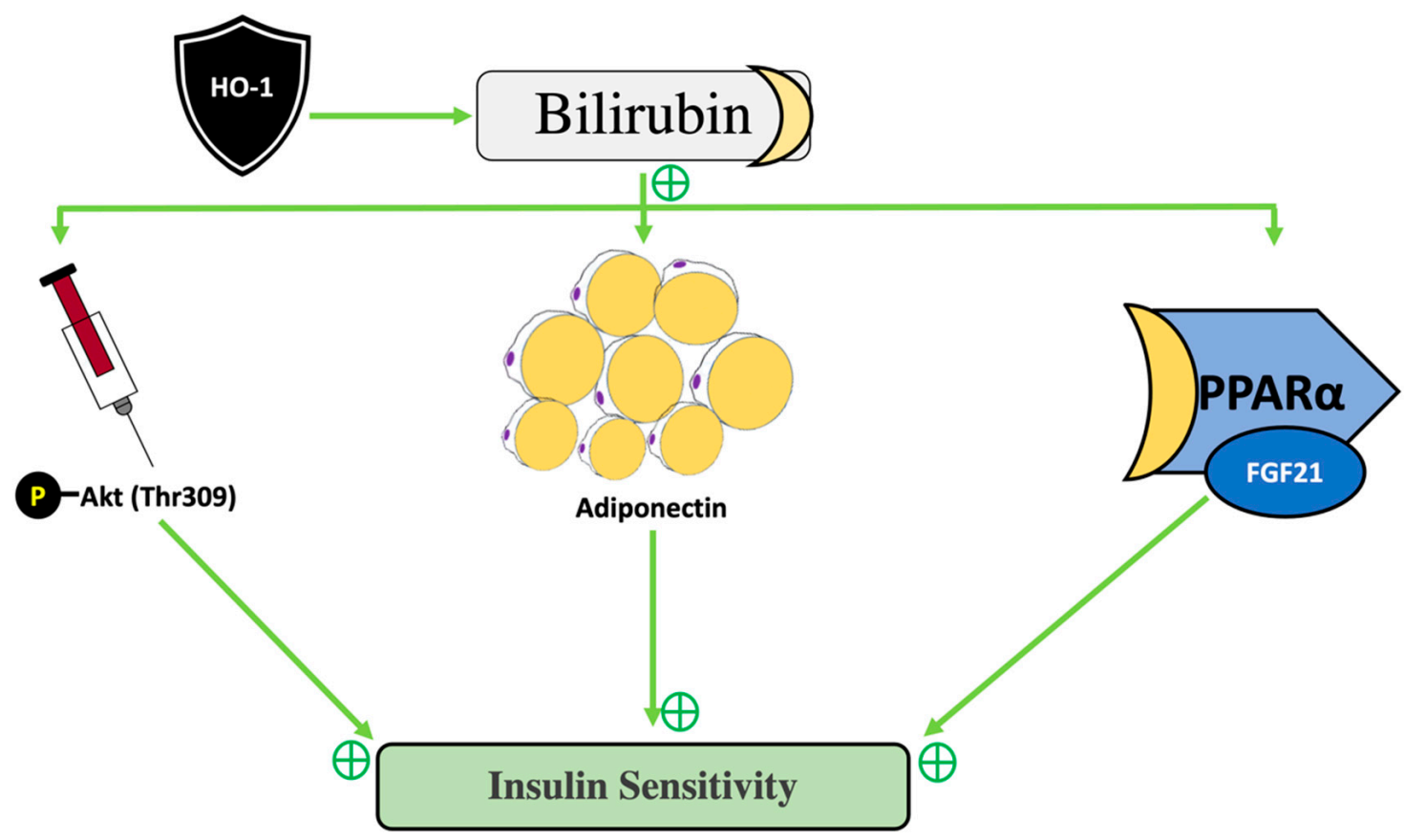

Figure 6. Model of how HO-1-bilirubin improves insulin sensitivity. Upregulation of HO-1-bilirubin is a multifactorial influencer of different metabolic processes such as induction phosphorylated Akt (Thr309), adiponectin production, and activation of PPAR $\alpha$-FGF21 pathways. 


\section{The Signaling Mechanisms of Heme Oxygenase and Bilirubin in Metabolism}

\subsection{Generation and Catabolism of Bilirubin}

Bilirubin is a tetrapyrrole compound formed from the catabolism of heme to biliverdin that is converted to bilirubin by biliverdin reductase (BVR) [17,41,42,118-122]. Tetrapyrroles are seen as an orange-yellow pigment, which may indicate underlying disease processes if extremely elevated $(>150 \mu \mathrm{M})$ in the skin (jaundice) or the urine [41]. When erythrocytes (red blood cells) are lysed, the hemoglobin is broken down into heme and protoporphyrin. The heme is oxidatively cleaved by the enzyme heme oxygenase (HO), yielding biliverdin, iron, and carbon monoxide (CO) [41]. This biliverdin can be converted to bilirubin through the cytosolic enzyme biliverdin reductase [123-125]. The conversion to bilirubin has been empirically shown to produce potent antioxidant effects that can regulate cellular redox reactions, decrease ROS, and decrease the activity of NADPH oxidase [3]. Bilirubin circulates bound to water-soluble albumin, where it is transferred to the hepatocyte as unconjugated bilirubin. Then, bilirubin is conjugated by the UDP glucuronosyltransferase 1A1 (UGT1A1) enzyme [121,126]. Once conjugated, bilirubin is then metabolized by colonic bacterial proteases and is either reabsorbed into the hepatobiliary system as urobilinogen or excreted in the feces and urine as stercobilin or urobilin, respectively [122]. The bilirubin pathway (illustrated and described in more detail elsewhere [17,41,42,119-122,126]) is increased with exercise [70], and a better understanding of the pathway regulation may identify areas that alter the bilirubin half-life that might lead to pathological consequences.

\subsection{Biliverdin Reductase and Metabolism}

While there are limited studies showing that BVRA is regulated by exercise [70], there have been supporting studies showing a role for the enzyme in metabolism [50,51,124,125,127]. Adipocyte-specific deletion of BVRA results in adipocyte hypertrophy and increased inflammation while decreasing mitochondrial number and markers of adipocyte browning such as PPAR $\alpha$ and $\beta 3$ adrenergic receptor (Adrb3) [127]. The loss of adipocyte BVRA also decreases insulin signaling in white adipose tissue contributing to increased fasting hyperglycemia in knockout mice [127]. These results agree with the finding from obese human patients who exhibit lower levels of BVRA, increased levels of inflammation, and increased adipocyte size [128]. CRISPR knockout of BVRA in hepatocytes and kidney proximal tubules cells induces oxidative stress and lipid accumulation [124,125]. Similarly, mice with a global knockout of BVRA have increased oxidative stress [41]. Deficiencies in BVRA also correlate with brain insulin resistance in Alzheimer's disease patients $[129,130]$. Administration of BVRA peptides improved intranasal insulin treatment in a mouse model of Alzheimer's disease, suggesting a potential therapeutic role for targeting BVRA for treatment [131].

BVRA also plays an essential role in the development of metabolic diseases associated with obesity, like NAFLD. Hepatocyte-specific BVRA knockout mice develop more severe dietary-induced NAFLD as compared to wild-type littermates [50]. The loss of hepatocyte BVRA increases activation of glycogen synthase kinase 3beta (GSK3 $\beta$ ) via decreased levels of serine 9 (Ser9) phosphorylation which in turn increases serine 73 (Ser73) phosphorylation of PPAR $\alpha$, increasing protein turnover and decreasing its transcriptional activity [50]. Interestingly, reduced adipocyte levels in BVRA in obese human patients resulted in significantly more hepatic steatosis and NAFLD [128]. These results suggest that BVRA can have both direct and indirect effects to contribute to hepatic steatosis and the development of NAFLD. More studies are needed to determine factors that regulate BVRA expression and how these are affected by exercise.

\subsection{Bilirubin and Metabolic Dysfunction}

Bilirubin was once believed to act only as a toxic bile substance and end-product. However, more recent studies have uncovered potential metabolic benefits of greater yet subclinical bilirubin concentrations. These include its role in ROS scavenging, anti-inflammatory properties, and reduction in adipocyte size from increased fat oxidation [94,132,133]. While 
marked extreme hyperbilirubinemia $(>150 \mu \mathrm{M})$ can be a sign of a more ominous clinical diagnosis, raised basal concentrations are also associated with protecting metabolic function (25-50 $\mu \mathrm{M}$ as discussed in [41]). The metabolic syndrome [134] is associated with increased insulin resistance and oxidative stress, which can also lend significant inflammatory and cardiovascular risk factors. Increased serum bilirubin concentration acts as a protective factor against the development of MetS. Subjects with increased basal bilirubin levels have a lower odds ratio to develop MetS [134]. It is thought this observation is due to the antioxidant, anti-inflammatory, and hormonal properties of bilirubin (discussed in more detail above). Conversely, in subjects diagnosed with metabolic syndrome, serum bilirubin is typically reduced ( $<10 \mu \mathrm{M}$, discussed further in [41]) [135]. Thus, the clinical assessment of serum bilirubin may have some future utility as a screening or prediction tool for those with high risk for metabolic dysfunction. In support of this, coronary artery disease severity was recently predicted with an odds ratio of 0.155 (95\% confidence interval), revealing an inverse relationship between bilirubin and CAD severity [136]. NAFLD was also predicted in patients with an odds ratio of 0.88 (95\% confidence interval), showing a strong inverse relationship between serum bilirubin and NAFLD [137]. A study of obese children showed that those with NAFLD had the lowest serum bilirubin [133]. Low bilirubin has also been associated with a greater risk of cerebral deep white matter lesions in healthy subjects [138], suggesting that low levels may impair cognitive function or lead to stroke [139-141]. These studies might suggest that increasing bilirubin levels could be therapeutic for improving metabolic dysfunction and reducing stroke risk. Factors that induce heme oxygenase production of bilirubin, such as nutraceuticals, may have several benefits [63]. These studies highlight a potential protective effect of bilirubin against metabolic disease and should be examined further to elucidate more of its positive benefits.

\section{Strategies to Improve Metabolic Outcomes through Nutraceuticals}

\subsection{The Influence of Diet on Antioxidants}

Fresh fruit and vegetable intake represent the largest source of dietary antioxidants that are essential in maintaining health [142]. A great deal of research has evaluated fruit and vegetable intake as a means to counter the inflammation that has been attributed to nearly all chronic diseases of modern society, with many studies demonstrating a strong inverse correlation between fruit and vegetable intake and inflammatory markers [143,144]. Much of the research concerning dietary antioxidants and inflammation has centered on the Mediterranean diet due to its emphasis on fresh fruit and vegetable intake. Both cross-sectional and longitudinal trials have demonstrated a substantial lowering effect for the Mediterranean diet on a wide variety of inflammatory markers, including IL-6, IL-7, IL-19, CRP, and TNF $\alpha$ [145-147]. This has prompted the use of the Mediterranean diet in hopes of managing metabolic and vascular diseases, endocrine disorders, and some cancers [148-150]. Elucidation of specific antioxidants, and the benefits of dietary supplementation, have been a focus for many current research studies, giving rise to various nutraceuticals. Below, we describe the effects of such nutraceuticals and their beneficial actions on the HO-1 pathway and inflammation.

\subsection{The Benefits of Moderately Raising Plasma Bilirubin}

Natural substances that raise plasma bilirubin have been of interest for reducing adiposity [63]. One herbal method that is gaining interest in elevating plasma bilirubin is the use of the milk thistle plant (Silybum marianum) [63]. The plant contains a mix of polyphenols such as p-coumaric, vanillic acid, silybin, and $\alpha$-tocopherol [151,152]. The primary compound in milk thistle that is considered the active component that increases plasma bilirubin is the silymarin flavonoids that suppress hepatic UGT1A1 [153]. Silymarin may protect against liver injury and hepatic fat accumulation [154-156]. However, how milk thistle or silymarin might function combined with exercise in reducing adiposity is unknown. 
Bilirubin is a potent endogenous antioxidant that the body uses to support oxidative balance [17,41,42,119-122]. Plasma bilirubin has been empirically correlated with decreased risk for oxidative disorders such as coronary artery disease (CAD) [42,119]. The theory of action stemmed from individuals with Gilbert Syndrome, who have a mutation in the UGT1A1 gene, which causes defective processing of bilirubin $[47,126]$. Hence, lower hepatic UGT1A1 causes higher plasma unconjugated bilirubin [47]. Individuals with Gilbert Syndrome were found to have decreased incidence of CAD [157]. Previous studies postulate that unconjugated bilirubin is fluxing back into cells and acting as a scavenging agent of oxidative radicals. However, researchers have also hypothesized that elevated serum bilirubin acts as a marker that could predict greater expression or inducibility of intracellular HO-1, which will increase the intracellular concentration of bilirubin [132]. Using HPLC-TLS, these researchers detected bilirubin levels within vascular endothelial cells. They also showed that bilirubin within these vascular endothelial cells could effectively modulate HO-1 upregulation [158]. These findings suggest strong potential for developing pharmacotherapeutics that can target and upregulate this intrinsic antioxidant system within the vascular endothelium through the induction of $\mathrm{HO}-1$ and help prevent or follow the progression of cardiovascular disease. This has the potential to lend more focused antioxidant and anti-inflammatory therapeutic approaches.

\subsection{Vitamin D Repletion}

Vitamin D is an important secosteroid in understanding metabolic disease [159]. Vitamin $\mathrm{D}$ deficiency (defined as a $25(\mathrm{OH}) \mathrm{D}$ level less than $20 \mathrm{ng} / \mathrm{dL}$ ) is common and is associated with decreased muscle endurance, function, and strength [160-167]. Vitamin D deficiency is connected to muscle metabolic perturbations, including insulin resistance [168-170], and is linked to mitochondrial dysfunction [171] in both young and aged adults. Vitamin D deficiency is highly prevalent in obesity without vitamin D supplementation [172,173]. Obese adults are commonly prescribed a high-dose vitamin D repletion protocol to combat vitamin $\mathrm{D}$ deficiency and obesity-associated vitamin $\mathrm{D}$ resistance. Aggressive vitamin D repletion to correct the deficiency is linked to improved muscle mitochondrial function $[171,174]$. Increasing vitamin D status is consistently associated with skeletal muscle lipid deposition and distribution [175-178]. There is also evidence that vitamin D may improve hepatic steatosis with just 4-weeks of supplementation [179].

Calcitriol, the active form of vitamin $\mathrm{D}\left[1,25(\mathrm{OH})_{2} \mathrm{D}_{3}\right]$, is the only form that can bind to the Vitamin D receptor (VDR). The VDR is a nuclear receptor transcription factor that controls gene expression changes that improve mitochondrial function in myotubes [180], insulin sensitivity, and myocellular lipid partitioning in high fat-treated SkM cells [181]. In humans, we found that vitamin D combined with aerobic exercise potentiated the metabolic benefit of training by producing the most intramyocellular lipid (IMCL) loss and increasing skeletal muscle tissue-level $\mathrm{VO}_{2}$ in older adults at risk for metabolic dysfunction [182]. These benefits were greater than when providing vitamin D repletion or exercising independently. These observations are consistent with reports that vitamin D coupled with exercise has positively affected muscle mitochondrial function [171,174]. In addition, VDR expression in SkM was increased by exercise [183]. Vitamin D supplementation has been associated with muscle regeneration and repair $[123,145,146]$, suggesting an additive effect when combined with vitamin $\mathrm{D}$ repletion.

In addition to these findings, vitamin $\mathrm{D}$ has been described to have anti-inflammatory effects and is linked to insulin sensitivity and immuno-modulation [184-186]. Recent work has also highlighted a novel role of vitamin D in upregulating HO-1 expression in intestinal cells and reduced expression of macrophage $\mathrm{HO}-1$ with an associated reduction in conjugated bilirubin [187]. Vitamin D has been shown to block the activation of M-1 macrophages, increase activation of M-2 macrophages, and impair monocyte/macrophage recruitment [187]. Collectively, these data suggest that vitamin D may ameliorate metabolic dysfunction by altering lipid availability for oxidation in response to exercise training and 
may help regulate inflammatory pathways. These observations require further exploration in obesity-inflammation studies.

Along with evidence that vitamin D repletion augments oxidative metabolism [171,174], we show in a muscle cell line that active calcitriol treatment altered total lipid, lipid species content, and increased gene expression of PLIN2, a lipid coatomer protein that facilitates IMCL availability for $\beta$-oxidation $[188,189]$. PLIN2-containing lipid droplets are also preferentially used during moderate-intensity exercise [190], suggesting that increased PLIN2 expression may increase lipolytic potential. In vitro findings from our group $[180,181]$ indicate increased PLIN2-associated lipid accumulation and lipolysis after calcitriol treatment. These changes suggest an increased lipid flux-defined here as the rate at which lipids pass through SkM via IMCL accumulation and oxidation —and, by association, a decrease in lipid-mediated pathologies [191]. These cell culture results suggest that vitamin D is involved in muscle lipid packaging, partitioning, and mitochondrial lipid oxidation. Together with data showing that exercise improves muscle sensitivity to vitamin D storage and retention [192], evidence of muscle adaptations to the combination of vitamin D supplementation with exercise are tightly connected with improved mitochondrial function and may serve an integral role in delaying stagnant ectopic fat infiltration and metabolic dysfunction.

\subsection{Nitrate from Foods and Dietary Supplements}

Dietary nitrate is predominately found in green leafy vegetables and concentrated food sources (e.g., beetroot juice) and dietary supplements. Physically active individuals commonly use this EE to increase plasma nitrate concentrations and subsequently increase nitric oxide availability [193]. Increasing nitric oxide via the nitrate-nitrite-NO signaling pathway (with supplemental dietary nitrate) has been shown to decrease NADPH oxidase-derived oxidative stress via HO-1 induction and reduce p47phox expression [194]. Metabolically, nitrate has also been shown to reduce the oxygen cost of exercise [195] and improve exercise tolerance, economy, and performance. These benefits may also extend to those newly committed to exercise to lose fat and improve metabolic function. In addition to these observations, it seems reasonable that dietary nitrate may also work alongside exercise to preserve endothelial function [196]. Basaqr et al. recently found that four weeks of concentrated beetroot juice combined with vitamin $C$ improved endothelial function and the lipid profile of overweight subjects with evidence of endothelial dysfunction [197]. The exact mechanism of action to explain these findings is unknown but is partially explained by the combined antioxidant effects of vitamin $C$ and concentrated dietary nitrate supplements to decrease oxidative stress [198-201]. Improvements in blood lipids from others suggest that dietary nitrate supplementation with the addition of vitamin $C$ (or other nutraceutical antioxidants) may be a valuable dietary approach alongside exercise to improve metabolic and cardiovascular health $[60,61]$. Future studies could determine how these impact exercise, inflammation, and metabolic outcomes.

\subsection{Vitamin E Supplementation}

Vitamin $E(\alpha / \gamma$-tocopherol) is one of the most important dietary antioxidants that play a critical role as a radical savaging agent and mechanistic inducer [202]. Vitamin E acts as a potent antioxidant to neutralize free radicals and superoxide by using its free hydroxyl group to accept unpaired electrons [203]. Furthermore, unlike other dietary antioxidants (e.g., vitamin C, carotenoids, etc.), Vitamin E is uniquely connected with exercise-induced oxidative stress and insulin sensitivity. The regulation and distribution of Vitamin $\mathrm{E}$ are controlled by alpha-tocopherol transfer protein $(\alpha$-TTP) in the liver. $\alpha$-TTP secretes Vitamin $\mathrm{E}$ from the liver by releasing $\alpha$-tocopherol into the circulation. However, this mechanism is still not clearly understood [204]. Data suggests that $\alpha$-TTP is lower when the $\alpha$-tocopherol levels are low and subjects with an $\alpha$-TTP gene (TTPA) knockout presented with symptoms of vitamin E serum deficiency [202]. The $\alpha$-TTP is also known to be induced by hypoxic states and stress-induced free radical production [205]. The administration of vitamin $\mathrm{E}$ in hypoxic states (similar to hypoxia observed with high-intensity exercise) has mitigated ROS- 
related biochemical changes in many tissues by preventing increases in malondialdehyde and myeloperoxidase and protecting against lipid peroxidation [206]. This hypoxia-based regulative mechanism has the potential to be evident during times of exercise; however, this hypothesis has yet to be tested. The rationale behind this hypothesis is that during exercise, hypoxia-induction of $\alpha$-TTP will help increase serum $\alpha$-tocopherol and protect the cells from free-radical damage during exercise-induced oxidative stress. This tocopherol can also provide non -antioxidant functions and induce mRNA levels of transcription factors, PPAR $\gamma$, and the hormone, adiponectin $[207,208]$. Adiponectin and PPAR $\gamma$ are activated by vitamin $\mathrm{E}$ and are known to improve insulin sensitivity in diabetes. The vitamin E-induction of PPAR $\gamma$ is not through direct binding but through the increase in 15d-PGJ2, a commonly described ligand of PPAR $\gamma$ [208] that is also known to induce HO-1 through p38 MAP kinase and the Nrf-2 pathway [209]. This induction may further increase exercise-induced HO-1 activation and influence the BVRA-bilirubin-PPAR $\alpha$ axis. Both Vitamin E and PPARs are valuable targets in hepatic protection in non-alcoholic hepatic steatosis and fibrosis [210].

\section{Conclusions}

Exercise has clear benefits in reducing adiposity and inflammation while improving insulin sensitivity. A deeper understanding of the mechanisms of how exercise functions to improve these beneficial actions is needed. While bilirubin was once thought to be a harmful bile substance, current research argues otherwise and that slightly elevated levels have numerous health benefits against metabolic dysfunction. Studies on how exercise influences factors such as heme oxygenase, BVRA, and UGT1A1 that control bilirubin's turnover (half-life) are needed. Furthermore, nutraceuticals that activate and control these pathways might be beneficial in improving weight-loss regimens. Investigations in these areas might also benefit patients with inflammatory disorders as increasing plasma bilirubin has anti-inflammatory properties that probably originate from its antioxidant and hormone (as a ligand for PPAR $\alpha$ ) properties. Future work determining the interplay of exercise and nutraceuticals has many health benefits to help a broad spectrum of diseases.

Author Contributions: T.D.H.J. conceived the project. N.R.D. created graphic illustrations for Figures 1-3 and 6 using PowerPoint; D.E.S. developed Figure 4 using BioRender.com (accessed on 9 December 2021); T.D.H.J. generated Figure 5 using OmniGraffle. D.T.T., N.R.D., K.D.F., D.E.S. and T.D.H.J. wrote the manuscript and reviewed and revised the final manuscript. All authors have read and agreed to the published version of the manuscript.

Funding: This work was supported by the National Institutes of Health, National Institute of Diabetes and Digestive and Kidney Diseases 1R01DK121797-01A1 (T.D.H.J.) and 1R01DK126884-01A1 (D.E.S.), the National Heart, Lung and Blood Institute K01HL-125445 (T.D.H.J.) and P01 HL05197-11 (D.E.S.), and the National Institute of General Medical Sciences P20GM104357-02 (D.E.S.). The content is solely the responsibility of the authors and does not necessarily represent the official views of the National Institutes of Health.

Conflicts of Interest: T.D.H.J. and D.E.S. have submitted patents on bilirubin and obesity-related disorders.

\section{References}

1. Budui, S.L.; Rossi, A.P.; Zamboni, M. The pathogenetic bases of sarcopenia. Clin. Cases Miner. Bone Metab. 2015, 12, 22-26. [CrossRef]

2. Dewidar, B.; Kahl, S.; Pafili, K.; Roden, M. Metabolic liver disease in diabetes-From mechanisms to clinical trials. Metabolism 2020, 111, 154299. [CrossRef] [PubMed]

3. Takada, S.; Sabe, H.; Kinugawa, S. Abnormalities of Skeletal Muscle, Adipocyte Tissue, and Lipid Metabolism in Heart Failure: Practical Therapeutic Targets. Front. Cardiovasc. Med. 2020, 12, 79. [CrossRef] [PubMed]

4. Allison, D.B.; Fontaine, K.R.; Manson, J.E.; Stevens, J.; VanItallie, T.B. Annual deaths attributable to obesity in the United States. JAMA 1999, 282, 1530-1538. [CrossRef]

5. Williams, E.P.; Mesidor, M.; Winters, K.; Dubbert, P.M.; Wyatt, S.B. Overweight and Obesity: Prevalence, Consequences, and Causes of a Growing Public Health Problem. Curr. Obes. Rep. 2015, 4, 363-370. [CrossRef] 
6. $\quad$ Ogden, C.L.; Carroll, M.D.; Kit, B.K.; Flegal, K.M. Prevalence of obesity among adults: United States, 2011-2012. NCHS Data Brief 2013, 131, 1-8.

7. National Center for Health Statistics. Health, United States, 2016: With Chart Book on Long-Term Trends in Health; National Center for Health Statistics: Hyattsville, MD, USA, 2017.

8. Thomas, D.M.; Bouchard, C.; Church, T.; Slentz, C.; Kraus, W.E.; Redman, L.M.; Martin, C.K.; Silva, A.M.; Vossen, M.; Westerterp, K.; et al. Why do individuals not lose more weight from an exercise intervention at a defined dose? An energy balance analysis. Obes. Rev. 2012, 13, 835-847. [CrossRef]

9. Thomas, D.M.; Kyle, T.K.; Stanford, F.C. The gap between expectations and reality of exercise-induced weight loss is associated with discouragement. Prev. Med. 2015, 81, 357-360. [CrossRef] [PubMed]

10. King, N.A.; Caudwell, P.; Hopkins, M.; Byrne, N.M.; Colley, R.; Hills, A.P.; Stubbs, J.R.; Blundell, J.E. Metabolic and behavioral compensatory responses to exercise interventions: Barriers to weight loss. Obesity 2007, 15, 1373-1383. [CrossRef]

11. Kirwan, J.P.; Sacks, J.; Nieuwoudt, S. The essential role of exercise in the management of type 2 diabetes. Clevel. Clin. J. Med. 2017, 84, S15-S21. [CrossRef]

12. Winzer, E.B.; Woitek, F.; Linke, A. Physical Activity in the Prevention and Treatment of Coronary Artery Disease. J. Am. Heart Assoc. 2018, 7, e007725. [CrossRef] [PubMed]

13. Whitsett, M.; VanWagner, L.B. Physical activity as a treatment of non-alcoholic fatty liver disease: A systematic review. World J. Hepatol. 2015, 7, 2041-2052. [CrossRef] [PubMed]

14. Vina, J.; Sanchis-Gomar, F.; Martinez-Bello, V.; Gomez-Cabrera, M.C. Exercise acts as a drug; the pharmacological benefits of exercise. Br. J. Pharmacol. 2012, 167, 1-12. [CrossRef] [PubMed]

15. Singh, R. The importance of exercise as a therapeutic agent. Malays. J. Med. Sci. 2002, 9, 7-16.

16. Bird, S.R.; Hawley, J.A. Update on the effects of physical activity on insulin sensitivity in humans. BMJ. Open Sport Exerc. Med. 2017, 2, e000143. [CrossRef] [PubMed]

17. O'Brien, L.; Hosick, P.A.; John, K.; Stec, D.E.; Hinds, T.D., Jr. Biliverdin reductase isozymes in metabolism. Trends Endocrinol. Metab. 2015, 26, 212-220. [CrossRef]

18. Colberg, S.R.; Sigal, R.J.; Fernhall, B.; Regensteiner, J.G.; Blissmer, B.J.; Rubin, R.R.; Chasan-Taber, L.; Albright, A.L.; Braun, B.; American College of Sports, M.; et al. Exercise and type 2 diabetes: The American College of Sports Medicine and the American Diabetes Association: Joint position statement. Diabetes Care 2010, 33, e147-e167. [CrossRef]

19. Bruning, R.S.; Sturek, M. Benefits of exercise training on coronary blood flow in coronary artery disease patients. Prog. Cardiovasc. Dis. 2015, 57, 443-453. [CrossRef]

20. Gilbertson, N.M.; Eichner, N.Z.M.; Heiston, E.M.; Gaitan, J.M.; Francois, M.E.; Mehaffey, J.H.; Hassinger, T.E.; Hallowell, P.T.; Weltman, A.; Malin, S.K. A low-calorie diet with or without interval exercise training improves adiposopathy in obese women. Appl. Physiol. Nutr. Metab. 2019, 44, 1057-1064. [CrossRef]

21. Sargeant, J.A.; Gray, L.J.; Bodicoat, D.H.; Willis, S.A.; Stensel, D.J.; Nimmo, M.A.; Aithal, G.P.; King, J.A. The effect of exercise training on intrahepatic triglyceride and hepatic insulin sensitivity: A systematic review and meta-analysis. Obes. Rev. 2018, 19, 1446-1459. [CrossRef]

22. Francois, M.E.; Gilbertson, N.M.; Eichner, N.Z.M.; Heiston, E.M.; Fabris, C.; Breton, M.; Mehaffey, J.H.; Hassinger, T.; Hallowell, P.T.; Malin, S.K. Combining Short-Term Interval Training with Caloric Restriction Improves ss-Cell Function in Obese Adults. Nutrients 2018, 10, 717. [CrossRef]

23. Mora-Rodriguez, R.; Ortega, J.F.; Ramirez-Jimenez, M.; Moreno-Cabanas, A.; Morales-Palomo, F. Insulin sensitivity improvement with exercise training is mediated by body weight loss in subjects with metabolic syndrome. Diabetes Metab. 2019, 46, 210-218. [CrossRef] [PubMed]

24. Haskell, W.L.; Lee, I.M.; Pate, R.R.; Powell, K.E.; Blair, S.N.; Franklin, B.A.; Macera, C.A.; Heath, G.W.; Thompson, P.D.; Bauman, A. Physical activity and public health: Updated recommendation for adults from the American College of Sports Medicine and the American Heart Association. Med. Sci. Sports Exerc. 2007, 39, 1423-1434. [CrossRef] [PubMed]

25. Donnelly, J.E.; Blair, S.N.; Jakicic, J.M.; Manore, M.M.; Rankin, J.W.; Smith, B.K.; American College of Sports Medicine. American College of Sports Medicine Position Stand. Appropriate physical activity intervention strategies for weight loss and prevention of weight regain for adults. Med. Sci. Sports Exerc. 2009, 41, 459-471. [CrossRef] [PubMed]

26. Diabetes Prevention Program Research, G. Long-term effects of lifestyle intervention or metformin on diabetes development and microvascular complications over 15-year follow-up: The Diabetes Prevention Program Outcomes Study. Lancet Diabetes Endocrinol. 2015, 3, 866-875. [CrossRef]

27. De Vries, T.I.; Dorresteijn, J.A.N.; van der Graaf, Y.; Visseren, F.L.J.; Westerink, J. Heterogeneity of Treatment Effects From an Intensive Lifestyle Weight Loss Intervention on Cardiovascular Events in Patients with Type 2 Diabetes: Data From the Look AHEAD Trial. Diabetes Care 2019, 42, 1988-1994. [CrossRef] [PubMed]

28. Flack, K.D.; Hays, H.M.; Moreland, J.; Long, D.E. Exercise for Weight Loss: Further Evaluating Energy Compensation with Exercise. Med. Sci. Sports Exerc. 2020, 52, 2466-2475. [CrossRef]

29. Flack, K.D.; Ufholz, K.; Johnson, L.; Fitzgerald, J.S.; Roemmich, J.N. Energy compensation in response to aerobic exercise training in overweight adults. Am. J. Physiol. Regul. Integr. Comp. Physiol. 2018, 315, R619-R626. [CrossRef] 
30. Rosenkilde, M.; Auerbach, P.; Reichkendler, M.H.; Ploug, T.; Stallknecht, B.M.; Sjodin, A. Body fat loss and compensatory mechanisms in response to different doses of aerobic exercise-A randomized controlled trial in overweight sedentary males. Am. J. Physiol. Regul. Integr. Comp. Physiol. 2012, 303, R571-R579. [CrossRef]

31. Church, T.S.; Martin, C.K.; Thompson, A.M.; Earnest, C.P.; Mikus, C.R.; Blair, S.N. Changes in weight, waist circumference and compensatory responses with different doses of exercise among sedentary, overweight postmenopausal women. PLoS ONE 2009, 4, e4515. [CrossRef]

32. King, N.A.; Hopkins, M.; Caudwell, P.; Stubbs, R.J.; Blundell, J.E. Individual variability following 12 weeks of supervised exercise: Identification and characterization of compensation for exercise-induced weight loss. Int. J. Obes. 2008, 32, 177-184. [CrossRef] [PubMed]

33. King, N.A.; Tremblay, A.; Blundell, J.E. Effects of exercise on appetite control: Implications for energy balance. Med. Sci. Sports Exerc. 1997, 29, 1076-1089. [CrossRef] [PubMed]

34. Tryfidou, D.V.; McClean, C.; Nikolaidis, M.G.; Davison, G.W. NA Damage Following Acute Aerobic Exercise: A Systematic Review and Meta-analysis. Sports Med. 2020, 50, 103-127. [CrossRef] [PubMed]

35. Steinbacher, P.; Eckl, P. Impact of oxidative stress on exercising skeletal muscle. Biomolecules 2015, 5, 356-377. [CrossRef]

36. Fittipaldi, S.; Mercatelli, I.; Caporossi, D. Role of exercise-induced reactive oxygen species in the modulation of heat shock protein response. Free Radic. Res. 2014, 48, 52-70. [CrossRef]

37. Kawamura, T.; Muraoka, I. Exercise-Induced Oxidative Stress and the Effects of Antioxidant Intake from a Physiological Viewpoint. Antioxidants 2018, 7, 119. [CrossRef] [PubMed]

38. Gomez-Cabrera, M.C.; Domenech, E.; Vina, J. Moderate exercise is an antioxidant: Upregulation of antioxidant genes by training Free Radic. Biol. Med. 2008, 44, 126-131. [CrossRef] [PubMed]

39. John, K.; Marino, J.S.; Sanchez, E.R.; Hinds, T.D., Jr. The glucocorticoid receptor: Cause of or cure for obesity? Am. J. Physiol. Endocrinol. Metab. 2016, 310, E249-E257. [CrossRef] [PubMed]

40. Muller, F.L.; Song, W.; Jang, Y.C.; Liu, Y.; Sabia, M.; Richardson, A.; Van Remmen, H. Denervation-induced skeletal muscle atrophy is associated with increased mitochondrial ROS production. Am. J. Physiol. Regul. Integr. Comp. Physiol. 2007, 293, R1159-R1168. [CrossRef] [PubMed]

41. Creeden, J.F.; Gordon, D.M.; Stec, D.E.; Hinds, T.D., Jr. Bilirubin as a metabolic hormone: The physiological relevance of low levels. Am. J. Physiol. Endocrinol. Metab. 2021, 320, E191-E207. [CrossRef]

42. Hinds, T.D., Jr.; Stec, D.E. Bilirubin, a Cardiometabolic Signaling Molecule. Hypertension 2018, 72, 788-795. [CrossRef] [PubMed]

43. Ndisang, J.F. Role of Heme Oxygenase in Inflammation, Insulin-Signalling, Diabetes and Obesity. Mediat. Inflamm. 2010, 2010, 359732. [CrossRef]

44. $\quad$ Dong, H.; Huang, H.; Yun, X.; Kim, D.-s.; Yue, Y.; Wu, H.; Sutter, A.; Chavin, K.D.; Otterbein, L.E.; Adams, D.B.; et al. Bilirubin increases insulin sensitivity in leptin-receptor deficient and diet-induced obese mice through suppression of ER stress and chronic inflammation. Endocrinology 2014, 155, 818-828. [CrossRef] [PubMed]

45. Takei, R.; Inoue, T.; Sonoda, N.; Kohjima, M.; Okamoto, M.; Sakamoto, R.; Inoguchi, T.; Ogawa, Y. Bilirubin reduces visceral obesity and insulin resistance by suppression of inflammatory cytokines. PLoS ONE 2019, 14, e0223302. [CrossRef]

46. Hinds, T.D., Jr.; Creeden, J.F.; Gordon, D.M.; Stec, D.F.; Donald, M.C.; Stec, D.E. Bilirubin Nanoparticles Reduce Diet-Induced Hepatic Steatosis, Improve Fat Utilization, and Increase Plasma beta-Hydroxybutyrate. Front. Pharm. 2020, 11, 594574. [CrossRef] [PubMed]

47. Hinds, T.D., Jr.; Hosick, P.A.; Hankins, M.W.; Nestor-Kalinoski, A.; Stec, D.E. Mice with hyperbilirubinemia due to Gilbert's Syndrome polymorphism are resistant to hepatic steatosis by decreased serine 73 phosphorylation of PPARalpha. Am. J. Physiol. Endocrinol. Metab. 2017, 312, E244-E252. [CrossRef]

48. Zhang, M.; Nakamura, K.; Kageyama, S.; Lawal, A.O.; Gong, K.W.; Bhetraratana, M.; Fujii, T.; Sulaiman, D.; Hirao, H.; Bolisetty, S.; et al. Myeloid HO-1 modulates macrophage polarization and protects against ischemia-reperfusion injury. JCI Insight 2018, 3, e120596. [CrossRef]

49. Kato, H.; Amersi, F.; Buelow, R.; Melinek, J.; Coito, A.J.; Ke, B.; Busuttil, R.W.; Kupiec-Weglinski, J.W. Heme Oxygenase-1 Overexpression Protects Rat Livers from Ischemia/Reperfusion Injury with Extended Cold Preservation. Am. J. Transplant. 2001, 1,121-128. [CrossRef]

50. Hinds, T.D., Jr.; Burns, K.A.; Hosick, P.A.; McBeth, L.; Nestor-Kalinoski, A.; Drummond, H.A.; AlAmodi, A.A.; Hankins, M.W.; Vanden Heuvel, J.P.; Stec, D.E. Biliverdin reductase A attenuates hepatic steatosis by inhibition of glycogen synthase kinase (GSK) 3beta phosphorylation of serine 73 of peroxisome proliferator-activated receptor (PPAR) alpha. J. Biol. Chem. 2016, 291, 25179-25191. [CrossRef]

51. Chen, W.; Tumanov, S.; Fazakerley, D.J.; Cantley, J.; James, D.E.; Dunn, L.L.; Shaik, T.; Suarna, C.; Stocker, R. Bilirubin deficiency renders mice susceptible to hepatic steatosis in the absence of insulin resistance. Redox Biol. 2021, 47, 102152. [CrossRef]

52. Gobert, A.P.; Verriere, T.; Asim, M.; Barry, D.P.; Piazuelo, M.B.; de Sablet, T.; Delgado, A.G.; Bravo, L.E.; Correa, P.; Peek, R.M., Jr.; et al. Heme oxygenase-1 dysregulates macrophage polarization and the immune response to Helicobacter pylori. J. Immunol. 2014, 193, 3013-3022. [CrossRef] [PubMed]

53. Li, M.; Kim, D.H.; Tsenovoy, P.L.; Peterson, S.J.; Rezzani, R.; Rodella, L.F.; Aronow, W.S.; Ikehara, S.; Abraham, N.G. Treatment of obese diabetic mice with a heme oxygenase inducer reduces visceral and subcutaneous adiposity, increases adiponectin levels, and improves insulin sensitivity and glucose tolerance. Diabetes 2008, 57, 1526-1535. [CrossRef] 
54. Ndisang, J.F.; Lane, N.; Syed, N.; Jadhav, A. Up-regulating the heme oxygenase system with hemin improves insulin sensitivity and glucose metabolism in adult spontaneously hypertensive rats. Endocrinology 2010, 151, 549-560. [CrossRef] [PubMed]

55. Lin, H.; Yu, C.-H.; Jen, C.-Y.; Cheng, C.-F.; Chou, Y.; Chang, C.-C.; Juan, S.-H. Adiponectin-mediated heme oxygenase-1 induction protects against iron-induced liver injury via a PPAR $\alpha$ dependent mechanism. Am. J. Pathol. 2010, 177, 1697-1709. [CrossRef]

56. Yang, M.; Kimura, M.; Ng, C.; He, J.; Keshvari, S.; Rose, F.J.; Barclay, J.L.; Whitehead, J.P. Induction of heme-oxygenase-1 (HO-1) does not enhance adiponectin production in human adipocytes: Evidence against a direct HO-1-Adiponectin axis. Mol. Cell. Endocrinol. 2015, 413, 209-216. [CrossRef]

57. Araujo, J.A.; Zhang, M.; Yin, F. Heme oxygenase-1, oxidation, inflammation, and atherosclerosis. Front. Pharm. 2012, 3, 119. [CrossRef] [PubMed]

58. Jais, A.; Einwallner, E.; Sharif, O.; Gossens, K.; Lu, T.T.-H.; Soyal, S.M.; Medgyesi, D.; Neureiter, D.; Paier-Pourani, J.; Dalgaard, K.; et al. Heme oxygenase-1 drives metaflammation and insulin resistance in mouse and man. Cell 2014, 158, 25-40. [CrossRef]

59. Ghio, A.J.; Case, M.W.; Soukup, J.M. Heme oxygenase activity increases after exercise in healthy volunteers. Free Radic. Res. 2018, 52, 267-272. [CrossRef]

60. Niess, A.M.; Passek, F.; Lorenz, I.; Schneider, E.M.; Dickhuth, H.-H.; Northoff, H.; Fehrenbach, E. Expression of the antioxidant stress protein heme oxygenase-1 (HO-1) in human leukocytes: Acute and adaptational responses to endurance exercise. Free Radic. Biol. Med. 1999, 26, 184-192. [CrossRef]

61. Kitamuro, T.; Takahashi, K.; Ogawa, K.; Udono-Fujimori, R.; Takeda, K.; Furuyama, K.; Nakayama, M.; Sun, J.; Fujita, H.; Hida, W.; et al. Bach1 functions as a hypoxia-inducible repressor for the heme oxygenase-1 gene in human cells. J. Biol. Chem. 2003, 278, 9125-9133. [CrossRef] [PubMed]

62. Reichard, J.F.; Sartor, M.A.; Puga, A. BACH1 is a specific repressor of HMOX1 that is inactivated by arsenite. J. Biol. Chem. 2008, 283, 22363-22370. [CrossRef]

63. Stec, D.E.; Hinds, T.D., Jr. Natural Product Heme Oxygenase Inducers as Treatment for Nonalcoholic Fatty Liver Disease. Int. J. Mol. Sci. 2020, 21, 9493. [CrossRef]

64. Kurata, S.; Matsumoto, M.; Nakajima, H. Transcriptional control of the heme oxygenase gene in mouse M1 cells during their TPA-induced differentiation into macrophages. J. Cell. Biochem. 1996, 62, 314-324. [CrossRef]

65. Falone, S.; Mirabilio, A.; Pennelli, A.; Cacchio, M.; Di Baldassarre, A.; Gallina, S.; Passerini, A.; Amicarelli, F. Differential impact of acute bout of exercise on redox- and oxidative damage-related profiles between untrained subjects and amateur runners. Physiol. Res. 2010, 59, 953-961. [CrossRef] [PubMed]

66. Wegiel, B.; Baty, C.J.; Gallo, D.; Csizmadia, E.; Scott, J.R.; Akhavan, A.; Chin, B.Y.; Kaczmarek, E.; Alam, J.; Bach, F.H.; et al. Cell surface biliverdin reductase mediates biliverdin-induced anti-inflammatory effects via phosphatidylinositol 3-kinase and Akt. J. Biol. Chem. 2009, 284, 21369-21378. [CrossRef] [PubMed]

67. Stechschulte, L.A.; Wuescher, L.; Marino, J.S.; Hill, J.W.; Eng, C.; Hinds, T.D., Jr. Glucocorticoid receptor beta stimulates Akt1 growth pathway by attenuation of PTEN. J. Biol. Chem. 2014, 289, 17885-17894. [CrossRef] [PubMed]

68. Hu, Z.Z.; Pei, G.C.; Wang, P.G.; Yang, J.; Zhu, F.M.; Guo, Y.J.; Wang, M.; Yao, Y.; Zeng, R.; Liao, W.H.; et al. Biliverdin Reductase A (BVRA) Mediates Macrophage Expression of Interleukin-10 in Injured Kidney. Int. J. Mol. Sci. 2015, 16, 22621-22635. [CrossRef]

69. Bisht, K.; Canesin, G.; Cheytan, T.; Li, M.; Nemeth, Z.; Csizmadia, E.; Woodruff, T.M.; Stec, D.E.; Bulmer, A.C.; Otterbein, L.E.; et al Deletion of Biliverdin Reductase A in Myeloid Cells Promotes Chemokine Expression and Chemotaxis in Part via a Complement C5a-C5aR1 Pathway. J. Immunol. 2019, 202, 2982-2990. [CrossRef] [PubMed]

70. Hinds, T.D., Jr.; Creeden, J.F.; Gordon, D.M.; Spegele, A.C.; Britton, S.L.; Koch, L.G.; Stec, D.E. Rats Genetically Selected for High Aerobic Exercise Capacity Have Elevated Plasma Bilirubin by Upregulation of Hepatic Biliverdin Reductase-A (BVRA) and Suppression of UGT1A1. Antioxidants 2020, 9, 889. [CrossRef]

71. Swift, D.L.; Johannsen, N.M.; Earnest, C.P.; Blair, S.N.; Church, T.S. Effect of different doses of aerobic exercise training on total bilirubin levels. Med. Sci. Sports Exerc. 2012, 44, 569-574. [CrossRef]

72. Witek, K.; Scislowska, J.; Turowski, D.; Lerczak, K.; Lewandowska-Pachecka, S.; Pokrywka, A. Total bilirubin in athletes, determination of reference range. Biol. Sport 2017, 34, 45-48. [CrossRef]

73. Priest, J.B.; Oei, T.O.; Moorehead, W.R. Exercise-induced changes in common laboratory tests. Am. J. Clin. Pathol. 1982, 77, 285-289. [CrossRef]

74. Loprinzi, P.D.; Abbott, K. Physical activity and total serum bilirubin levels among insulin sensitive and insulin resistant U.S. adults. J. Diabetes Metab. Disord. 2014, 13, 47. [CrossRef]

75. Fallon, K.E. The clinical utility of screening of biochemical parameters in elite athletes: Analysis of 100 cases. Br. J. Sports Med. 2008, 42, 334-337. [CrossRef] [PubMed]

76. Hammouda, O.; Chtouror, H.; Chaouachi, A.; Chahed, H.; Ferchichi, S.; Kallel, C.; Chamari, K.; Souissi, N. Effect of short-term maximal exercise on biochemical markers of muscle damage, total antioxidant status, and homocysteine levels in football players. Asian J. Sports Med. Clin. N. Am. 2012, 3, 239-246. [CrossRef]

77. Kratz, A.; Lewandowski, K.B.; Siegel, A.J.; Chun, K.Y.; Flood, J.G.; van Cott, E.M. Effect of marathon running on hematologic and biochemical laboratory parameters, including cardiac markers. Am. J. Clin. Pathol. 2002, 188, 856-863. [CrossRef]

78. Drukalec-Michalski, K.; Nowaczyk, P.; Glowka, N.; Ziobrowska, A.; Podgorski, T. Is a Four-Week Ketogenic Diet an Effective Nutritional Strategy in CrossFit-Trained Female and Male Athletes? Nutrients 2021, 13, 864. [CrossRef] 
79. Schoonjans, K.; Martin, G.; Staels, B.; Auwerx, J. Peroxisome proliferator-activated receptors, orphans with ligands and functions. Curr. Opin. Lipidol. 1997, 8, 159-166. [CrossRef] [PubMed]

80. Sodhi, K.; Puri, N.; Kim, D.H.; Hinds, T.D.; Stechschulte, L.A.; Favero, G.; Rodella, L.; Shapiro, J.I.; Jude, D.; Abraham, N.G. PPARdelta binding to heme oxygenase 1 promoter prevents angiotensin II-induced adipocyte dysfunction in Goldblatt hypertensive rats. Int. J. Obes. 2014, 38, 456-465. [CrossRef]

81. Fedorova, L.V.; Sodhi, K.; Gatto-Weis, C.; Puri, N.; Hinds, T.D., Jr.; Shapiro, J.I.; Malhotra, D. Peroxisome proliferator-activated receptor delta agonist, HPP593, prevents renal necrosis under chronic ischemia. PLoS ONE 2013, 8, e64436. [CrossRef]

82. Tyagi, S.; Gupta, P.; Saini, A.S.; Kaushal, C.; Sharma, S. The peroxisome proliferator-activated receptor: A family of nuclear receptors role in various diseases. J. Adv. Pharm. Technol. Res. 2011, 2, 236-240. [CrossRef]

83. Smedlund, K.B.; Sanchez, E.R.; Hinds, T.D., Jr. FKBP51 and the molecular chaperoning of metabolism. Trends Endocrinol. Metab. 2021, 32, 862-874. [CrossRef] [PubMed]

84. Hinds, T.D.; John, K.; McBeth, L.; Trabbic, C.J.; Sanchez, E.R. Timcodar (VX-853) Is a Non-FKBP12 Binding Macrolide Derivative That Inhibits PPAR $\gamma$ and Suppresses Adipogenesis. PPAR Res. 2016, 2016, 6218637. [CrossRef]

85. Hinds, T.D., Jr.; Stechschulte, L.A.; Cash, H.A.; Whisler, D.; Banerjee, A.; Yong, W.; Khuder, S.S.; Kaw, M.K.; Shou, W.; Najjar, S.M.; et al. Protein phosphatase 5 mediates lipid metabolism through reciprocal control of glucocorticoid receptor and peroxisome proliferator-activated receptor-gamma (PPARgamma). J. Biol. Chem. 2011, 286, 42911-42922. [CrossRef] [PubMed]

86. Chiu, M.; McBeth, L.; Sindhwani, P.; Hinds, T.D. Deciphering the Roles of Thiazolidinediones and PPARgamma in Bladder Cancer. PPAR Res. 2017, 2017, 4810672. [CrossRef]

87. Grygiel-Górniak, B. Peroxisome proliferator-activated receptors and their ligands: Nutritional and clinical implications-A review. Nutr. J. 2014, 13, 17. [CrossRef] [PubMed]

88. Stec, D.E.; Gordon, D.M.; Hipp, J.A.; Hong, S.; Mitchell, Z.L.; Franco, N.R.; Robison, J.W.; Anderson, C.D.; Stec, D.F.; Hinds, T.D., Jr. The loss of hepatic PPARalpha promotes inflammation and serum hyperlipidemia in diet-induced obesity. Am. J. Physiol. Regul. Integr. Comp. Physiol. 2019, 317, R733-R745. [CrossRef] [PubMed]

89. Hinds, T.D., Jr.; Kipp, Z.A.; Xu, M.; Yiannikouris, F.B.; Morris, A.J.; Stec, D.F.; Wahli, W.; Stec, D.E. Adipose-Specific PPARalpha Knockout Mice Have Increased Lipogenesis by PASK-SREBP1 Signaling and a Polarity Shift to Inflammatory Macrophages in White Adipose Tissue. Cells 2021, 11, 4. [CrossRef] [PubMed]

90. Marino, J.S.; Stechschulte, L.A.; Stec, D.E.; Nestor-Kalinoski, A.; Coleman, S.; Hinds, T.D., Jr. Glucocorticoid receptor beta induces hepatic steatosis by augmenting inflammation and inhibition of the peroxisome proliferator-activated receptor (PPAR) alpha. $J$. Biol. Chem. 2016, 291, 25776-25788. [CrossRef]

91. Gordon, D.M.; Hong, S.H.; Kipp, Z.A.; Hinds, T.D., Jr. Identification of Binding Regions of Bilirubin in the Ligand-Binding Pocket of the Peroxisome Proliferator-Activated Receptor-A (PPARalpha). Molecules 2021, 26, 2975. [CrossRef] [PubMed]

92. Gordon, D.M.; Neifer, K.L.; Hamoud, A.A.; Hawk, C.F.; Nestor-Kalinoski, A.L.; Miruzzi, S.A.; Morran, M.P.; Adeosun, S.O.; Sarver, J.G.; Erhardt, P.W.; et al. Bilirubin remodels murine white adipose tissue by reshaping mitochondrial activity and the coregulator profile of peroxisome proliferator-activated receptor alpha. J. Biol. Chem. 2020, 295, 9804-9822. [CrossRef]

93. Gordon, D.M.; Blomquist, T.M.; Miruzzi, S.A.; McCullumsmith, R.; Stec, D.E.; Hinds, T.D., Jr. RNA sequencing in human HepG2 hepatocytes reveals PPAR-alpha mediates transcriptome responsiveness of bilirubin. Physiol. Genom. 2019, 51, 234-240. [CrossRef] [PubMed]

94. Stec, D.E.; John, K.; Trabbic, C.J.; Luniwal, A.; Hankins, M.W.; Baum, J.; Hinds, T.D., Jr. Bilirubin Binding to PPAR $\alpha$ Inhibits Lipid Accumulation. PLoS ONE 2016, 11, e0153427. [CrossRef] [PubMed]

95. Rosenson, R.S. Fenofibrate: Treatment of hyperlipidemia and beyond. Expert Rev. Cardiovasc. 2008, 6, 1319-1330. [CrossRef]

96. Iemitsu, M.; Miyauchi, T.; Maeda, S.; Tanabe, T.; Takanashi, M.; Irukayama-Tomobe, Y.; Sakai, S.; Ohmori, H.; Matsuda, M.; Yamaguchi, I. Aging-induced decrease in the PPAR-alpha level in hearts is improved by exercise training. Am. J. Physiol. Heart Circ. Physiol. 2002, 283, H1750-H1760. [CrossRef]

97. Zhang, S.; Liu, Y.; Li, Q.; Dong, X.; Hu, H.; Hu, R.; Ye, H.; Wu, Y.; Hu, R.; Li, Y. Exercise improved rat metabolism by raising PPAR- $\alpha$. Int. J. Sports Med. 2011, 32, 568-573. [CrossRef] [PubMed]

98. Xu, J.; Stanislaus, S.; Chinookoswong, N.; Lau, Y.Y.; Hager, T.; Patel, J.; Ge, H.; Weiszmann, J.; Lu, S.-C.; Graham, M.; et al. Acute glucose-lowering and insulin-sensitizing action of FGF21 in insulin-resistant mouse models-Association with liver and adipose tissue effects. Am. J. Physiol.-Endocrinol. Metab. 2009, 297, E1105-E1114. [CrossRef]

99. Tezze, C.; Romanello, V.; Sandri, M. FGF21 as Modulator of Metabolism in Health and Disease. Front. Physiol. $2019,10,419$. [CrossRef]

100. Bougarne, N.; Weyers, B.; Desmet, S.J.; Deckers, J.; Ray, D.W.; Staels, B.; De Bosscher, K. Molecular Actions of PPAR $\alpha$ in Lipid Metabolism and Inflammation. Endocr. Rev. 2018, 39, 760-802. [CrossRef] [PubMed]

101. Contreras, A.V.; Torres, N.; Tovar, A.R. PPAR- $\alpha$ as a Key Nutritional and Environmental Sensor for Metabolic Adaptation. Adv. Nutr. 2013, 4, 439-452. [CrossRef] [PubMed]

102. Zhang, H.; He, Y.; Chung, P.K.; Tong, T.K.; Fu, F.H.; Chen, Y.; Jiao, G. Effects of 12 Weeks of Exercise on Hepatic TNF- $\alpha$ and PPAR $\alpha$ in an Animal Model of High-Fat Diet-Induced Nonalcoholic Steatohepatitis. J. Exerc. Sci. Fit. 2009, 7, 18-23. [CrossRef]

103. Tanimura, Y.; Aoi, W.; Takanami, Y.; Kawai, Y.; Mizushima, K.; Naito, Y.; Yoshikawa, T. Acute exercise increases fibroblast growth factor 21 in metabolic organs and circulation. Physiol. Rep. 2016, 4, e12828. [CrossRef] [PubMed] 
104. Muoio, D.M.; MacLean, P.S.; Lang, D.B.; Li, S.; Houmard, J.A.; Way, J.M.; Winegar, D.A.; Corton, J.C.; Dohm, G.L.; Kraus, W.E. Fatty acid homeostasis and induction of lipid regulatory genes in skeletal muscles of peroxisome proliferator-activated receptor (PPAR) alpha knock-out mice. Evidence for compensatory regulation by PPAR delta. J. Biol. Chem. 2002, $277,26089-26097$. [CrossRef]

105. Lopez-Leon, S.; Tuvblad, C.; Forero, D.A. Sports genetics: The PPARA gene and athletes' high ability in endurance sports. A systematic review and meta-analysis. Biol. Sport 2016, 33, 3-6. [CrossRef]

106. Russell, A.P.; Feilchenfeldt, J.; Schreiber, S.; Praz, M.; Crettenand, A.; Gobelet, C.; Meier, C.A.; Bell, D.R.; Kralli, A.; Giacobino, J.P.; et al. Endurance training in humans leads to fiber type-specific increases in levels of peroxisome proliferator-activated receptorgamma coactivator-1 and peroxisome proliferator-activated receptor-alpha in skeletal muscle. Diabetes 2003, 52, $2874-2881$. [CrossRef] [PubMed]

107. Fritz, T.; Krämer, D.K.; Karlsson, H.K.; Galuska, D.; Engfeldt, P.; Zierath, J.R.; Krook, A. Low-intensity exercise increases skeletal muscle protein expression of PPARdelta and UCP3 in type 2 diabetic patients. Diabetes Metab. Res. Rev. 2006, 22, $492-498$. [CrossRef]

108. Kannisto, K.; Chibalin, A.; Glinghammar, B.; Zierath, J.R.; Hamsten, A.; Ehrenborg, E. Differential expression of peroxisomal proliferator activated receptors alpha and delta in skeletal muscle in response to changes in diet and exercise. Int. J. Mol. Med. 2006, 17, 45-52.

109. Rachid, T.L.; Silva-Veiga, F.M.; Graus-Nunes, F.; Bringhenti, I.; Mandarim-de-Lacerda, C.A.; Souza-Mello, V. Differential actions of PPAR- $\alpha$ and PPAR- $\beta / \delta$ on beige adipocyte formation: A study in the subcutaneous white adipose tissue of obese male mice. PLOS ONE 2018, 13, e0191365. [CrossRef] [PubMed]

110. Varga, T.; Czimmerer, Z.; Nagy, L. PPARs are a unique set of fatty acid regulated transcription factors controlling both lipid metabolism and inflammation. Biochim. Biophys. Acta 2011, 1812, 1007-1022. [CrossRef]

111. Thomas, A.W.; Davies, N.A.; Moir, H.; Watkeys, L.; Ruffino, J.S.; Isa, S.A.; Butcher, L.R.; Hughes, M.G.; Morris, K.; Webb, R. Exercise-associated generation of PPAR $\gamma$ ligands activates PPAR $\gamma$ signaling events and upregulates genes related to lipid metabolism. J. Appl Physiol. 2012, 112, 806-815. [CrossRef] [PubMed]

112. Ma, X.; Wang, D.; Zhao, W.; Xu, L. Deciphering the Roles of PPAR $\gamma$ in Adipocytes via Dynamic Change of Transcription Complex. Front. Endocrinol. 2018, 9, 473. [CrossRef]

113. Vidal-Puig, A.J.; Considine, R.V.; Jimenez-Liñan, M.; Werman, A.; Pories, W.J.; Caro, J.F.; Flier, J.S. Peroxisome proliferatoractivated receptor gene expression in human tissues. Effects of obesity, weight loss, and regulation by insulin and glucocorticoids. J. Clin. Investig. 1997, 99, 2416-2422. [CrossRef] [PubMed]

114. Verreth, W.; Keyzer, D.D.; Pelat, M.; Verhamme, P.; Ganame, J.; Bielicki, J.K.; Mertens, A.; Quarck, R.; Benhabilès, N.; Marguerie, G.; et al. Weight Loss-Associated Induction of Peroxisome Proliferator-Activated Receptor- $\alpha$;and Peroxisome Proliferator-Activated Receptor- $\gamma$ Correlate with Reduced Atherosclerosis and Improved Cardiovascular Function in Obese Insulin-Resistant Mice. Circulation 2004, 110, 3259-3269. [CrossRef]

115. Wang, F.; Mullican, S.E.; DiSpirito, J.R.; Peed, L.C.; Lazar, M.A. Lipoatrophy and severe metabolic disturbance in mice with fat-specific deletion of PPAR $\gamma$. Proc. Natl. Acad. Sci. USA 2013, 110, 18656-18661. [CrossRef]

116. Jones, J.R.; Barrick, C.; Kim, K.-A.; Lindner, J.; Blondeau, B.; Fujimoto, Y.; Shiota, M.; Kesterson, R.A.; Kahn, B.B.; Magnuson, M.A Deletion of PPARgamma in adipose tissues of mice protects against high fat diet-induced obesity and insulin resistance. Proc. Natl. Acad. Sci. USA 2005, 102, 6207-6212. [CrossRef] [PubMed]

117. Liu, J.; Dong, H.; Zhang, Y.; Cao, M.; Song, L.; Pan, Q.; Bulmer, A.; Adams, D.B.; Dong, X.; Wang, H. Bilirubin Increases Insulin Sensitivity by Regulating Cholesterol Metabolism, Adipokines and PPAR $\gamma$ Levels. Sci. Rep. 2015, 5, 9886. [CrossRef]

118. Shiels, R.G.; Vidimce, J.; Pearson, A.G.; Matthews, B.; Wagner, K.-H.; Battle, A.R.; Sakellaris, H.; Bulmer, A.C. Unprecedented Microbial Conversion of Biliverdin into Bilirubin-10-sulfonate. Sci. Rep. 2019, 9, 2988. [CrossRef] [PubMed]

119. Hinds, T.D., Jr.; Stec, D.E. Bilirubin Safeguards Cardiorenal and Metabolic Diseases: A Protective Role in Health. Curr. Hypertens. Rep. 2019, 21, 87. [CrossRef]

120. Weaver, L.; Hamoud, A.R.; Stec, D.E.; Hinds, T.D., Jr. Biliverdin reductase and bilirubin in hepatic disease. Am. J. Physiol. Gastrointest. Liver Physiol. 2018, 314, G668-G676. [CrossRef]

121. Sundararaghavan, V.L.; Binepal, S.; Stec, D.E.; Sindhwani, P.; Hinds, T.D., Jr. Bilirubin, a new therapeutic for kidney transplant? Transpl. Rev. 2018, 32, 234-240. [CrossRef]

122. Hamoud, A.R.; Weaver, L.; Stec, D.E.; Hinds, T.D., Jr. Bilirubin in the Liver-Gut Signaling Axis. Trends Endocrinol. Metab. 2018, 29, 140-150. [CrossRef]

123. Adeosun, S.O.; Moore, K.H.; Lang, D.M.; Nwaneri, A.C.; Hinds, T.D., Jr.; Stec, D.E. A Novel Fluorescence-Based Assay for the Measurement of Biliverdin Reductase Activity. React. Oxyg. Species 2018, 5, 35-45. [CrossRef] [PubMed]

124. Gordon, D.M.; Adeosun, S.O.; Ngwudike, S.I.; Anderson, C.D.; Hall, J.E.; Hinds, T.D., Jr.; Stec, D.E. CRISPR Cas9-mediated deletion of biliverdin reductase A (BVRA) in mouse liver cells induces oxidative stress and lipid accumulation. Arch. Biochem. Biophys. 2019, 672, 108072. [CrossRef]

125. Adeosun, S.O.; Gordon, D.M.; Weeks, M.F.; Moore, K.H.; Hall, J.E.; Hinds, T.D., Jr.; Stec, D.E. Loss of biliverdin reductase-A promotes lipid accumulation and lipotoxicity in mouse proximal tubule cells. Am. J. Physiol. Ren. Physiol. 2018, 315, F323-F331. [CrossRef] 
126. Sundararaghavan, V.L.; Sindhwani, P.; Hinds, T.D., Jr. Glucuronidation and UGT isozymes in bladder: New targets for the treatment of uroepithelial carcinomas? Oncotarget 2017, 8, 3640-3648. [CrossRef] [PubMed]

127. Stec, D.E.; Gordon, D.M.; Nestor-Kalinoski, A.L.; Donald, M.C.; Mitchell, Z.L.; Creeden, J.F.; Hinds, T.D., Jr. Biliverdin Reductase A (BVRA) Knockout in Adipocytes Induces Hypertrophy and Reduces Mitochondria in White Fat of Obese Mice. Biomolecules 2020, 10, 387. [CrossRef]

128. Ceccarelli, V.; Barchetta, I.; Cimini, F.A.; Bertoccini, L.; Chiappetta, C.; Capoccia, D.; Carletti, R.; Di Cristofano, C.; Silecchia, G.; Fontana, M.; et al. Reduced Biliverdin Reductase-A Expression in Visceral Adipose Tissue is Associated with Adipocyte Dysfunction and NAFLD in Human Obesity. Int. J. Mol. Sci. 2020, 21, 9091. [CrossRef] [PubMed]

129. Barone, E.; Di Domenico, F.; Cassano, T.; Arena, A.; Tramutola, A.; Lavecchia, M.A.; Coccia, R.; Butterfield, D.A.; Perluigi, M. Impairment of biliverdin reductase-A promotes brain insulin resistance in Alzheimer disease: A new paradigm. Free Radic. Biol. Med. 2016, 91, 127-142. [CrossRef]

130. Triani, F.; Tramutola, A.; Di Domenico, F.; Sharma, N.; Butterfield, D.A.; Head, E.; Perluigi, M.; Barone, E. Biliverdin reductase-A impairment links brain insulin resistance with increased Abeta production in an animal model of aging: Implications for Alzheimer disease. Biochim. Biophys. Acta Mol. Basis Dis. 2018, 1864, 3181-3194. [CrossRef] [PubMed]

131. Barone, E.; Tramutola, A.; Triani, F.; Calcagnini, S.; Di Domenico, F.; Ripoli, C.; Gaetani, S.; Grassi, C.; Butterfield, D.A.; Cassano, T.; et al. Biliverdin Reductase-A Mediates the Beneficial Effects of Intranasal Insulin in Alzheimer Disease. Mol. Neurobiol. 2019, 56, 2922-2943. [CrossRef]

132. McCarty, M.F. Serum bilirubin may serve as a marker for increased heme oxygenase activity and inducibility in tissues-A rationale for the versatile health protection associated with elevated plasma bilirubin. Med. Hypotheses 2013, 81, 607-610. [CrossRef] [PubMed]

133. Lin, Y.C.; Chang, P.F.; Hu, F.C.; Chang, M.H.; Ni, Y.H. Variants in the UGT1A1 gene and the risk of pediatric nonalcoholic fatty liver disease. Pediatrics 2009, 124, e1221-e1227. [CrossRef] [PubMed]

134. Verlaan, S.; Maier, A.B.; Bauer, J.M.; Bautmans, I.; Brandt, K.; Donini, L.M.; Maggio, M.; McMurdo, M.E.; Mets, T.; Seal, C.; et al Sufficient levels of 25-hydroxyvitamin D and protein intake required to increase muscle mass in sarcopenic older adults-The PROVIDE study. Clin. Nutr. 2017, 37, 551-557. [CrossRef]

135. Lee, M.J.; Jung, C.H.; Kang, Y.M.; Hwang, J.Y.; Jang, J.E.; Leem, J.; Park, J.Y.; Kim, H.K.; Lee, W.J. Serum bilirubin as a predictor of incident metabolic syndrome: A 4-year retrospective longitudinal study of 6205 initially healthy Korean men. Diabetes Metab. 2014, 40, 305-309. [CrossRef] [PubMed]

136. Turfan, M.; Duran, M.; Poyraz, F.; Yayla, C.; Akboga, M.K.; Sahinarslan, A.; Tavil, Y.; Pasaoglu, H.; Boyaci, B. Inverse relationship between serum total bilirubin levels and severity of disease in patients with stable coronary artery disease. Coron. Artery Dis. 2013, 24, 29-32. [CrossRef] [PubMed]

137. Jang, B.K. Elevated serum bilirubin levels are inversely associated with nonalcoholic fatty liver disease. Clin. Mol. Hepatol. 2012, 18, 357-359. [CrossRef]

138. Higuchi, S.; Kabeya, Y.; Uchida, J.; Kato, K.; Tsukada, N. Low Bilirubin Levels Indicate a High Risk of Cerebral Deep White Matter Lesions in Apparently Healthy Subjects. Sci. Rep. 2018, 8, 6473. [CrossRef] [PubMed]

139. Garde, E.; Mortensen, E.L.; Krabbe, K.; Rostrup, E.; Larsson, H.B. Relation between age-related decline in intelligence and cerebral white-matter hyperintensities in healthy octogenarians: A longitudinal study. Lancet 2000, 356, 628-634. [CrossRef]

140. Verdelho, A.; Madureira, S.; Moleiro, C.; Ferro, J.M.; Santos, C.O.; Erkinjuntti, T.; Pantoni, L.; Fazekas, F.; Visser, M.; Waldemar, G.; et al. White matter changes and diabetes predict cognitive decline in the elderly: The LADIS study. Neurology 2010, 75, 160-167. [CrossRef] [PubMed]

141. Debette, S.; Markus, H.S. The clinical importance of white matter hyperintensities on brain magnetic resonance imaging: Systematic review and meta-analysis. BMJ 2010, 341, c3666. [CrossRef] [PubMed]

142. Benzie, I.F. Evolution of dietary antioxidants. Comp. Biochem. Physiol. Part A Mol. Integr. Physiol. 2003, 136, 113-126. [CrossRef]

143. Watzl, B.; Kulling, S.E.; Moseneder, J.; Barth, S.W.; Bub, A. A 4-wk intervention with high intake of carotenoid-rich vegetables and fruit reduces plasma C-reactive protein in healthy, nonsmoking men. Am. J. Clin. Nutr. 2005, 82, 1052-1058. [CrossRef] [PubMed]

144. Nanri, A.; Moore, M.A.; Kono, S. Impact of C-reactive protein on disease risk and its relation to dietary factors. Asian Pac. J. Cancer Prev. 2007, 8, 167-177.

145. Esposito, K.; Marfella, R.; Ciotola, M.; Di Palo, C.; Giugliano, F.; Giugliano, G.; D’Armiento, M.; D’Andrea, F.; Giugliano, D. Effect of a mediterranean-style diet on endothelial dysfunction and markers of vascular inflammation in the metabolic syndrome: $\mathrm{A}$ randomized trial. JAMA 2004, 292, 1440-1446. [CrossRef]

146. Salas-Salvado, J.; Garcia-Arellano, A.; Estruch, R.; Marquez-Sandoval, F.; Corella, D.; Fiol, M.; Gomez-Gracia, E.; Vinoles, E.; Aros, F.; Herrera, C.; et al. Components of the Mediterranean-type food pattern and serum inflammatory markers among patients at high risk for cardiovascular disease. Eur. J. Clin. Nutr. 2008, 62, 651-659. [CrossRef]

147. Chrysohoou, C.; Panagiotakos, D.B.; Pitsavos, C.; Das, U.N.; Stefanadis, C. Adherence to the Mediterranean diet attenuates inflammation and coagulation process in healthy adults: The ATTICA Study. J. Am. Coll. Cardiol. 2004, 44, 152-158. [CrossRef]

148. Tuttolomondo, A.; Simonetta, I.; Daidone, M.; Mogavero, A.; Ortello, A.; Pinto, A. Metabolic and Vascular Effect of the Mediterranean Diet. Int. J. Mol. Sci. 2019, 20, 4716. [CrossRef] [PubMed]

149. Mentella, M.C.; Scaldaferri, F.; Ricci, C.; Gasbarrini, A.; Miggiano, G.A.D. Cancer and Mediterranean Diet: A Review. Nutrients 2019, 11, 2059. [CrossRef] 
150. Martín-Peláez, S.; Fito, M.; Castaner, O. Mediterranean Diet Effects on Type 2 Diabetes Prevention, Disease Progression, and Related Mechanisms. A Review. Nutrients 2020, 12, 2236. [CrossRef]

151. Meddeb, W.; Rezig, L.; Abderrabba, M.; Lizard, G.; Mejri, M. Tunisian Milk Thistle: An Investigation of the Chemical Composition and the Characterization of Its Cold-Pressed Seed Oils. Int. J. Mol. Sci. 2017, 18, 2582. [CrossRef]

152. Pittala, V.; Vanella, L.; Salerno, L.; Romeo, G.; Marrazzo, A.; Di Giacomo, C.; Sorrenti, V. Effects of Polyphenolic Derivatives on Heme Oxygenase-System in Metabolic Dysfunctions. Curr. Med. Chem. 2018, 25, 1577-1595. [CrossRef] [PubMed]

153. Suk, J.; Jasprova, J.; Biedermann, D.; Petraskova, L.; Valentova, K.; Kren, V.; Muchova, L.; Vitek, L. Isolated Silymarin Flavonoids Increase Systemic and Hepatic Bilirubin Concentrations and Lower Lipoperoxidation in Mice. Oxid. Med. Cell. Longev. 2019, 2019, 6026902. [CrossRef] [PubMed]

154. Bechynska, K.; Kosek, V.; Fenclova, M.; Muchova, L.; Smid, V.; Suk, J.; Chalupsky, K.; Sticova, E.; Hurkova, K.; Hajslova, J.; et al. The Effect of Mycotoxins and Silymarin on Liver Lipidome of Mice with Non-Alcoholic Fatty Liver Disease. Biomolecules 2021, 11, 1723. [CrossRef] [PubMed]

155. Ni, X.; Wang, H. Silymarin attenuated hepatic steatosis through regulation of lipid metabolism and oxidative stress in a mouse model of nonalcoholic fatty liver disease (NAFLD). Am. J. Transl. Res. 2016, 8, 1073-1081.

156. Clichici, S.; Olteanu, D.; Nagy, A.L.; Oros, A.; Filip, A.; Mircea, P.A. Silymarin inhibits the progression of fibrosis in the early stages of liver injury in CCl(4)-treated rats. J. Med. Food 2015, 18, 290-298. [CrossRef]

157. Gupta, N.; Singh, T.; Chaudhary, R.; Garg, S.K.; Sandhu, G.S.; Mittal, V.; Gupta, R.; Bodin, R.; Sule, S. Bilirubin in coronary artery disease: Cytotoxic or protective? World J. Gastrointest. Pharm. 2016, 7, 469-476. [CrossRef]

158. Ziberna, L.; Martelanc, M.; Franko, M.; Passamonti, S. Bilirubin is an Endogenous Antioxidant in Human Vascular Endothelial Cells. Sci. Rep. 2016, 6, 29240. [CrossRef]

159. Cesari, M.; Incalzi, R.A.; Zamboni, V.; Pahor, M. Vitamin D hormone: A multitude of actions potentially influencing the physical function decline in older persons. Geriatr. Gerontol. Int. 2011, 11, 133-142. [CrossRef]

160. Sato, Y.; Iwamoto, J.; Kanoko, T.; Satoh, K. Low-dose vitamin D prevents muscular atrophy and reduces falls and hip fractures in women after stroke: A randomized controlled trial. Cerebrovasc. Dis. 2005, 20, 187-192. [CrossRef]

161. Hamilton, B. Vitamin D and human skeletal muscle. Scand. J. Med. Sci. Sports 2010, 20, 182-190. [CrossRef]

162. Girgis, C.M. Integrated therapies for osteoporosis and sarcopenia: From signaling pathways to clinical trials. Calcif. Tissue Int. 2015, 96, 243-255. [CrossRef]

163. Bunout, D.; Barrera, G.; Leiva, L.; Gattas, V.; de la Maza, M.P.; Avendano, M.; Hirsch, S. Effects of vitamin D supplementation and exercise training on physical performance in Chilean vitamin D deficient elderly subjects. Exp. Gerontol. 2006, 41, 746-752. [CrossRef]

164. Houston, D.K.; Tooze, J.A.; Neiberg, R.H.; Hausman, D.B.; Johnson, M.A.; Cauley, J.A.; Bauer, D.C.; Cawthon, P.M.; Shea, M.K.; Schwartz, G.G.; et al. 25-hydroxyvitamin D status and change in physical performance and strength in older adults: The Health, Aging, and Body Composition Study. Am. J. Epidemiol. 2012, 176, 1025-1034. [CrossRef] [PubMed]

165. Bischoff-Ferrari, H.A.; Dietrich, T.; Orav, E.J.; Hu, F.B.; Zhang, Y.; Karlson, E.W.; Dawson-Hughes, B. Higher 25-hydroxyvitamin D concentrations are associated with better lower-extremity function in both active and inactive persons aged $>$ or $=60 \mathrm{y}$. Am. J. Clin. Nutr. 2004, 80, 752-758. [CrossRef]

166. Brunner, F.; Schmid, A.; Sheikhzadeh, A.; Nordin, M.; Yoon, J.; Frankel, V. Effects of aging on Type II muscle fibers: A systematic review of the literature. J. Aging Phys. Act. 2007, 15, 336-348. [CrossRef]

167. Muir, S.W.; Montero-Odasso, M. Effect of vitamin D supplementation on muscle strength, gait and balance in older adults: A systematic review and meta-analysis. J. Am. Geriatr. Soc. 2011, 59, 2291-2300. [CrossRef]

168. Ford, E.S.; Ajani, U.A.; McGuire, L.C.; Liu, S. Concentrations of serum vitamin D and the metabolic syndrome among U.S. adults. Diabetes Care 2005, 28, 1228-1230. [CrossRef]

169. Liu, E.; Meigs, J.B.; Pittas, A.G.; McKeown, N.M.; Economos, C.D.; Booth, S.L.; Jacques, P.F. Plasma 25-hydroxyvitamin d is associated with markers of the insulin resistant phenotype in nondiabetic adults. J. Nutr. 2009, 139, 329-334. [CrossRef]

170. Scragg, R.; Sowers, M.; Bell, C.; Third National, H.; Nutrition Examination, S. Serum 25-hydroxyvitamin D, diabetes, and ethnicity in the Third National Health and Nutrition Examination Survey. Diabetes Care 2004, 27, 2813-2818. [CrossRef] [PubMed]

171. Sinha, A.; Hollingsworth, K.G.; Ball, S.; Cheetham, T. Improving the vitamin D status of vitamin D deficient adults is associated with improved mitochondrial oxidative function in skeletal muscle. J. Clin. Endocrinol. Metab. 2013, 98, E509-E513. [CrossRef] [PubMed]

172. Daniel, D.; Hardigan, P.; Bray, N.; Penzell, D.; Savu, C. The incidence of vitamin D deficiency in the obese: A retrospective chart review. J. Community Hosp. Intern. Med. Perspect 2015, 5, 26069. [CrossRef] [PubMed]

173. Vranic, L.; Mikolasevic, I.; Milic, S. Vitamin D Deficiency: Consequence or Cause of Obesity? Medicina 2019, 55, 541. [CrossRef] [PubMed]

174. Ryan, Z.C.; Craig, T.A.; Folmes, C.D.; Wang, X.; Lanza, I.R.; Schaible, N.S.; Salisbury, J.L.; Nair, K.S.; Terzic, A.; Sieck, G.C.; et al. 1alpha,25-Dihydroxyvitamin D3 Regulates Mitochondrial Oxygen Consumption and Dynamics in Human Skeletal Muscle Cells. J. Biol. Chem. 2016, 291, 1514-1528. [CrossRef] [PubMed]

175. Tagliafico, A.S.; Ameri, P.; Bovio, M.; Puntoni, M.; Capaccio, E.; Murialdo, G.; Martinoli, C. Relationship between fatty degeneration of thigh muscles and vitamin D status in the elderly: A preliminary MRI study. AJR Am. J. Roentgenol. 2010, 194, 728-734. [CrossRef] [PubMed] 
176. Gilsanz, V.; Kremer, A.; Mo, A.O.; Wren, T.A.; Kremer, R. Vitamin D status and its relation to muscle mass and muscle fat in young women. J. Clin. Endocrinol. Metab. 2010, 95, 1595-1601. [CrossRef]

177. Redzic, M.; Powell, D.K.; Thomas, D.T. Vitamin D status is related to intramyocellular lipid in older adults. Endocrine 2014, 47, 854-861. [CrossRef] [PubMed]

178. Scott, D.; Joham, A.; Teede, H.; Gibson-Helm, M.; Harrison, C.; Cassar, S.; Hutchison, S.; Ebeling, P.R.; Stepto, N.; de Courten, B. Associations of Vitamin D with Inter- and Intra-Muscular Adipose Tissue and Insulin Resistance in Women with and without Polycystic Ovary Syndrome. Nutrients 2016, 8, 774. [CrossRef] [PubMed]

179. Papapostoli, P.; Lammert, F.; Stokes, C.S. Effect of Short-Term Vitamin D Correction on Hepatic Steatosis as Quantified by Controlled Attenuation Parameter (CAP). J. Gastrointest. Liver Dis. 2016, 25, 175-181. [CrossRef] [PubMed]

180. Schnell, D.M.; Walton, R.G.; Vekaria, H.J.; Sullivan, P.G.; Bollinger, L.M.; Peterson, C.A.; Thomas, D.T. Vitamin D produces a perilipin 2-dependent increase in mitochondrial function in C2C12 myotubes. J. Nutr. Biochem. 2019, 65, 83-92. [CrossRef]

181. Jefferson, G.E.; Schnell, D.M.; Thomas, D.T.; Bollinger, L.M. Calcitriol concomitantly enhances insulin sensitivity and alters myocellular lipid partitioning in high fat-treated skeletal muscle cells. J. Physiol. Biochem. 2017, 73, 613-621. [CrossRef]

182. Thomas, D.T.; Schnell, D.M.; Redzic, M.; Zhao, M.; Abraha, H.; Jones, D.; Brim, H.; Yu, G. Local In Vivo Measures of Muscle Lipid and Oxygen Consumption Change in Response to Combined Vitamin D Repletion and Aerobic Training in Older Adults. Nutrients 2019, 11, 930. [CrossRef] [PubMed]

183. Makanae, Y.; Ogasawara, R.; Sato, K.; Takamura, Y.; Matsutani, K.; Kido, K.; Shiozawa, N.; Nakazato, K.; Fujita, S. Acute bout of resistance exercise increases vitamin D receptor protein expression in rat skeletal muscle. Exp. Physiol. 2015, 100, $1168-1176$. [CrossRef] [PubMed]

184. Giulietti, A.; van Etten, E.; Overbergh, L.; Stoffels, K.; Bouillon, R.; Mathieu, C. Monocytes from type 2 diabetic patients have a pro-inflammatory profile. 1,25-Dihydroxyvitamin D(3) works as anti-inflammatory. Diabetes Res. Clin. Pract. 2007, 77, 47-57. [CrossRef]

185. Di Rosa, M.; Malaguarnera, M.; Nicoletti, F.; Malaguarnera, L. Vitamin D3: A helpful immuno-modulator. Immunology 2011, 134, 123-139. [CrossRef]

186. Jablonski, K.; Chonchol, M.; Pierce, G.; Walker, A.E.; Seals, D.R. 25-Hydroxyvitamin D deficiency is associated with inflammationlinked vascular endothelial dysfunction in middle-aged and older adults. Hypertension 2010, 57, 63-69. [CrossRef]

187. Yin, K.; Agrawal, D.K. Vitamin D and inflammatory diseases. J. Inflamm. Res. 2014, 7, 69-87. [CrossRef]

188. Wolins, N.E.; Quaynor, B.K.; Skinner, J.R.; Tzekov, A.; Croce, M.A.; Gropler, M.C.; Varma, V.; Yao-Borengasser, A.; Rasouli, N.; Kern, P.A.; et al. OXPAT/PAT-1 is a PPAR-induced lipid droplet protein that promotes fatty acid utilization. Diabetes 2006, 55, 3418-3428. [CrossRef]

189. Bosma, M.; Hesselink, M.K.C.; Sparks, L.M.; Timmers, S.; Ferraz, M.J.; Mattijssen, F.; van Beurden, D.; Schaart, G.; de Baets, M.H.; Verheyen, F.K.; et al. Perilipin 2 Improves Insulin Sensitivity in Skeletal Muscle Despite Elevated Intramuscular Lipid Levels. Diabetes 2012, 61, 2679-2690. [CrossRef]

190. Shepherd, S.O.; Cocks, M.; Tipton, K.D.; Ranasinghe, A.M.; Barker, T.A.; Burniston, J.G.; Wagenmakers, A.J.; Shaw, C.S. Preferential utilization of perilipin 2-associated intramuscular triglycerides during $1 \mathrm{~h}$ of moderate-intensity endurance-type exercise. Exp. Physiol. 2012, 97, 970-980. [CrossRef]

191. Funai, K.; Semenkovich, C.F. Skeletal muscle lipid flux: Running water carries no poison. Am. J. Physiol. Endocrinol. Metab. 2011, 301, E245-E251. [CrossRef]

192. Abboud, M.; Puglisi, D.A.; Davies, B.N.; Rybchyn, M.; Whitehead, N.P.; Brock, K.E.; Cole, L.; Gordon-Thomson, C.; Fraser, D.R.; Mason, R.S. Evidence for a specific uptake and retention mechanism for 25-hydroxyvitamin D (25OHD) in skeletal muscle cells. Endocrinology 2013, 154, 3022-3030. [CrossRef] [PubMed]

193. Thomas, D.T.; Erdman, K.A.; Burke, L.M. American College of Sports Medicine joint position statement: Nutrition and athletic performance. Med. Sci. Sports Exerc. 2016, 48, 543-568. [CrossRef] [PubMed]

194. Tian, R.; Peng, R.; Yang, Z.; Peng, Y.; Lu, N. Supplementation of dietary nitrate attenuated oxidative stress and endothelial dysfunction in diabetic vasculature through inhibition of NADPH oxidase. Nitric Oxide 2020, 96, 54-63. [CrossRef] [PubMed]

195. Jones, A.M. Influence of dietary nitrate on the physiological determinants of exercise performance: A critical review. Appl. Physiol. Nutr. Metab. 2014, 39, 1019-1028. [CrossRef]

196. Velmurugan, S.; Ming Gan, J.; Rathod, K.; Khambata, R.; Ghosh, M.; Hartley, A. Dietary nitrate improves vascular function in patients with hypercholesterolemia: A randomized, double-blind, placebo-controlled study. Am. J. Clin. Nutr. 2016, 103, 25-38. [CrossRef]

197. Basaqr, R.; Skleres, M.; Jayswal, R.; Thomas, D.T. The Effect of Dietary Nitrate and Vitamin C on Endothelial Function, Oxidative Stress, and Blood Lipids in Untreated Hypercholesterolemic Subjects: A Randomized Double-blind Crossover Study. Clin. Nutr. 2021, 40, 1851-1860. [CrossRef] [PubMed]

198. Ashor, A.W.; Siervo, M.; van der Velde, F.; Willis, N.D.; Mathers, J.C. Systematic review and meta-analysis of randomised controlled trials testing the effects of vitamin C supplementation on blood lipids. Clin. Nutr. 2016, 35, 626-637. [CrossRef]

199. Chambial, S.; Dwivedi, S.; Shukla, K.K.; John, P.J.; Sharma, P. Vitamin C in disease prevention and cure: An overview. Indian J. Clin. Biochem. 2013, 28, 314-328. [CrossRef]

200. Charlton-Menys, V.; Durrington, P. Human cholesterol metabolism and therapeutic molecules. Exp. Physiol. 2008, 93, 27-42. [CrossRef] 
201. McRae, M. Vitamin C supplementation lowers serum low-density lipoprotein cholesterol and triglycerides: A meta-analysis of 13 randomized controlled trials. J. Chiropr. Med. 2008, 7, 48-58. [CrossRef]

202. Galmés, S.; Serra, F.; Palou, A. Vitamin E Metabolic Effects and Genetic Variants: A Challenge for Precision Nutrition in Obesity and Associated Disturbances. Nutrients 2018, 10, 1919. [CrossRef] [PubMed]

203. Nakamura, Y.K.; Omaye, S.T. Vitamin E-modulated gene expression associated with ROS generation. J. Funct. Foods 2009, 1, 241-252. [CrossRef]

204. Traber, M.G. Vitamin E regulatory mechanisms. Annu. Rev. Nutr. 2007, 27, 347-362. [CrossRef] [PubMed]

205. Ulatowski, L.; Dreussi, C.; Noy, N.; Barnholtz-Sloan, J.; Klein, E.; Manor, D. Expression of the $\alpha$-tocopherol transfer protein gene is regulated by oxidative stress and common single-nucleotide polymorphisms. Free Radic. Biol. Med. 2012, 53, 2318-2326. [CrossRef] [PubMed]

206. Inan, C.; Kiliç, I.; Kilinç, K.; Kalayci, O.; Kotiloğlu, E. The effect of high dose antenatal vitamin E on hypoxia-induced changes in newborn rats. Pediatr. Res. 1995, 38, 685-689. [CrossRef]

207. Campbell, S.E.; Stone, W.L.; Whaley, S.G.; Qui, M.; Krishnan, K. Gamma (gamma) tocopherol upregulates peroxisome proliferator activated receptor (PPAR) gamma (gamma) expression in SW 480 human colon cancer cell lines. BMC Cancer 2003, 3, 25. [CrossRef] [PubMed]

208. Landrier, J.-F.o.; Gouranton, E.; El Yazidi, C.; Malezet, C.; Balaguer, P.; Borel, P.; Amiot, M.-J.p. Adiponectin Expression Is Induced by Vitamin E via a Peroxisome Proliferator-Activated Receptor $\gamma$-Dependent Mechanism. Endocrinology 2009, 150, $5318-5325$. [CrossRef] [PubMed]

209. Lim, H.-J.; Lee, K.-S.; Lee, S.; Park, J.-H.; Choi, H.-E.; Go, S.H.; Kwak, H.-J.; Parka, H.-Y. 15d-PGJ2 stimulates HO-1 expression through p38 MAP kinase and Nrf-2 pathway in rat vascular smooth muscle cells. Toxicol. Appl. Pharm. 2007, 223, 20-27. [CrossRef]

210. Polyzos, S.A.; Kang, E.S.; Boutari, C.; Rhee, E.J.; Mantzoros, C.S. Current and emerging pharmacological options for the treatment of nonalcoholic steatohepatitis. Metabolism 2020, 111, 154203. [CrossRef] [PubMed] 